\title{
Accountability for International Nutrition Commitment Initiatives
}

4 March 2014

Dolf J.H. te Lintelo,

Institute of Development Studies (IDS)

d.telintelo@ids.ac.uk

With inputs from Mark Roland and Courtney Tolmie of Results for Development, and research assistance from Paola Velasco and MariaFe Celi Reina. 


\section{CHILDREN'S \\ INVESTMENT FUND \\ FOUNDATION}

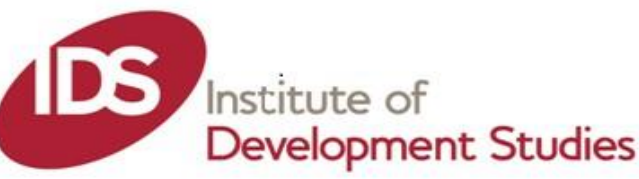

\section{Contents}

\section{EXECUTIVE SUMMARY}

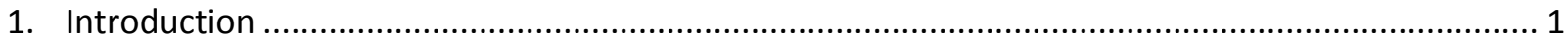

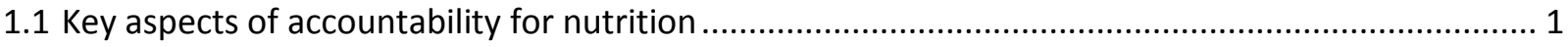

1.2 An overview of nutrition commitments made in international forums........................................ 4

1.3 Answerability for nutrition: information and evidence ............................................................ 11

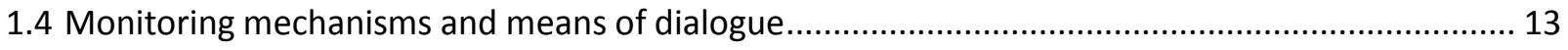

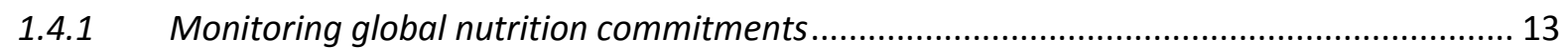

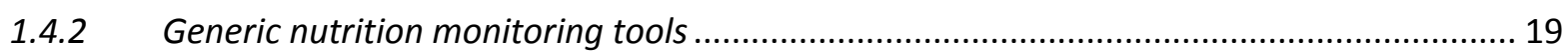

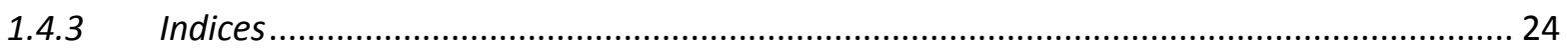

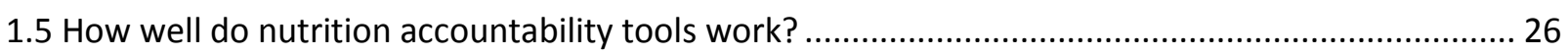

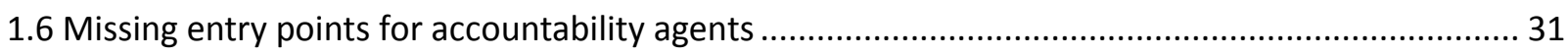

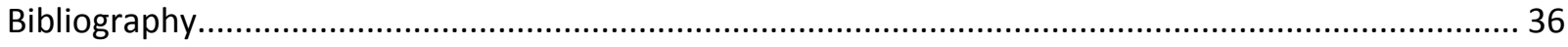




\section{EXECUTIVE SUMMARY}

This paper draws on secondary data to map out a proliferating set of international nutrition commitment initiatives, and assesses how these employ accountability mechanisms to support the delivery of financial and other commitments.

These accountability mechanisms are assessed for aspects of answerability, as well as enforcement (cf Schedler 1999). Answerability entails on the one hand, the right of the party that holds account to receive appropriate information from the accountable party on what is/will be done to achieve the nutrition inputs, outputs, outcomes and impacts towards which commitments have been made. On the other hand, accountable actors have an obligation to justify and clarify through public dialogue the choices of particular instruments, programmes and actions that seek to advance nutrition. The analysis of enforcement considers that accounting actors do not just critically challenge accountable persons but are able to reward good performance as well as impose negative sanctions in case of improper behavior.

The paper finds an expanding patchwork of international nutrition commitment initiatives having idiosyncratic and often underdeveloped accountability arrangements lacking clarity on who holds whom to account for what, by when, how and in accordance to what rules and norms. In general, aspects of answerability are better developed than aspects of enforcement.

International nutrition commitment initiatives are no longer the preserve of national governments and multilateral organisations, as individual and collectives of civil society organisations as well as private sector actors increasingly sign up. This diversity of actors needs to be better reflected in diverse accountability arrangements, and substantial if ad hoc experimentation is taking place towards this end. Whereas this has been so far most successful in terms of new forms of dialogue and consultation, monitoring and enforcement mechanisms are trailing.

Although common monitoring frameworks for setting out and reporting on commitments could be critical for achieving greater accountability, international summits somewhat narrowly focus attention on forging agreement on commitments. Afterwards, in many though not all cases, ad hoc and uncoordinated efforts are made at developing commitment monitoring mechanisms.

Common frameworks for setting out and reporting on nutrition commitments could be critical for achieving greater accountability. Current nutrition commitment initiatives could thus as a priority develop such frameworks, drawing on international best practice and paying sufficient attention to the diverse needs of public, private and third sector actors that sign up to these. Such reviews should take active account of the distinct monitoring approaches that are currently fashioned, emphasising governments (EWEC), donors, governments and civil society (SUN) and self-reporting.

Private sector companies have a critical role to play in food systems that make nutritious food accessible to the poor, and increasingly are signed up partners in international nutrition commitments such as the New Alliance. As yet, data on contributions of the private sector towards stated commitments, and processes steering its collection, are weakly developed. One key challenge here is to devise processes that can strike a meaningful balance between the interests of public accountability and private sector interests (e.g. commercial confidentiality). 
Similarly, individual and collectives of civil society organisations are to be held accountable for their performance. Encouragingly, some groups such as WorldVision and Interaction have already started to self-report on their performance vis-à-vis commitments. As much of this seems to be currently based on a trial and error approach, there are clear opportunities for learning within and across civil society and private sectors. More critical questions do however need to be asked about how self-monitoring can be done well, how it can be facilitated, as well as about the limits of self-monitoring (financial, practical or otherwise).

Even the most advanced international nutrition commitment initiatives, such as the Every Woman Every Child campaign and the SUN Movement have as yet only weakly developed enforcement mechanisms; this diminishes overall accountability. This review found it hard to build up an accurate picture of the implicit or explicit rules that govern stakeholders' delivery of commitments; the existence (leave be the application) of sanctions/rewards for (non)compliance; and the existence and effectiveness of possible mechanisms that enforce these. ${ }^{1}$ It is not clear if this is a matter of lack of demand and/or of design, and unclear under what political and economic conditions such logics of compliance might be developed. Arguably, where new nutrition commitments are made in future, a more explicit and upfront demand for clear rules of engagement and enforcement mechanisms may be made, for instance by civil society groups.

Conceivably, the lack of clarity on rules of engagement and enforcement mechanisms is a reflection of the highly collaborative nature of international nutrition commitments. This nature makes it hard for logics of compliance to develop and are thus often ruled by logics of participation that incrementally build ownership, greater commitment, mutual responsibility and partnerships. Moreover, greater complexity in the number and types of actors involved in international nutrition commitment initiatives may drive such a logic of participation. Yet, as incremental approaches need time to develop mature accountability mechanisms, international nutrition commitment initiatives may have to move away from short 4-5 year terms towards longer term (10-15 year) commitment horizons.

In all, the enforceability of international nutrition commitments should not be assumed as given. Indeed, delivery of nutrition commitments is significantly dependent on the goodwill of actors that make these commitments, and incentivised by social reputational effects (increased or lowered status) of adherence or breach of commitments.

\footnotetext{
${ }^{1}$ A primary research based methodology could have better addressed these questions.
} 


\section{Introduction}

In the last five years, nutrition has gained clear attention on the development agendas of national and international development partners, governments and political leaders. Prime Ministers from India (Manmohan Singh) and Great Britain (David Cameron) and Presidents from Malawi (Joyce Banda), Tanzania (Jakaya Kikwete) and Brazil (Dilma Rousseff) are amongst a growing group of political leaders that publicly speak out about the importance of enhancing child nutrition outcomes. Increasingly, public policies set numeric targets on enhanced nutrition outcomes to be achieved within clear timeframes, and financial commitments pledged towards the end. While such steps are extremely important for advancing national and international action on nutrition, what is less clear is how and to what extent development actors can be held accountable for delivering on these publicly expressed ambitions, pledges and commitments.

This paper explores the role of accountability mechanisms for these kinds of commitments seeking to accelerate child undernutrition reduction, at global and national levels. It maps out the landscape of commitments made by (particularly) governments, multilateral bodies and (to a smaller extent) international civil society organisations and critically explores the way in which an emerging set of accountability mechanisms currently take shape around such nutrition commitments.

The paper starts by setting out a brief conceptual discussion of key aspects of accountability, to provide a framework to guide the subsequent analysis of accountability for nutrition. The final section will offer suggestions on how these insights may support a strategic role for the Children's Investment Fund Foundation (CIFF) in accountability processes for nutrition.

\subsection{Key aspects of accountability for nutrition}

While accountability is a somewhat fuzzy concept, spawning various theories and approaches, a useful definition is provided in an influential paper by Andreas Schedler: ' $A$ is accountable to $B$ when $A$ is obliged to inform $B$ about A's (past or future) actions and decisions, to justify them, and to suffer punishment in the case of eventual misconduct' (1999: 17). Such a notion of political accountability involves two dimensions. Firstly, answerability: 'the obligation of public officials to inform about and to explain what they are doing; and enforcement, the capacity of accounting agencies to impose sanctions on powerholders who have violated their public duties' (ibid: 14 italics ed.). Answerability involves a dialogic relationship between accountable and accounting actors. Thus, people have a right to receive (a) information and (b) an explanation, which involves a corresponding obligation on accountable actors to provide all necessary information and to justify one's conduct (ibid:17). The second dimension, enforcement, considers that accounting actors do not just critically challenge accountable persons but are able to reward good performance as well as impose negative sanctions to 'eventually punish' them in case of improper behaviour (ibid: 15). This hence requires monitoring mechanisms that provide evidence on performance, and critically linked to these, enforcement mechanisms that incentivise actors to perform well. Where linkages between monitoring and enforcement are weak, accountability is weakened. Accountability thus involves the prevention of abuse of power, assuring compliance with 
procedures and standards, and improving performance and learning (Brinkerhoff 2004). Moreover, accountability needs to be exercised in public to be credible (Schedler 1999).

Critically, accountability is not an absolute concept that can be simply assessed as either existent or non-existent. Rather, 'evidence', 'ownership' and 'debate' (Droop et al, 2008) or 'information', 'justification', and 'reward/punishment' are continuous variables that exist in varying degrees, and in varying mixtures. Hence: "Even if one or two of them are missing we may still legitimately speak of acts of accountability" (Schedler 1999: 17).

What then does this mean in terms of accountability for public nutrition commitments? Firstly, it suggests that the purpose of accountability for nutrition is to enable individual citizens and citizen collectives, communities and actors within government to make those accountable answerable for the the appropriateness of substantive policies and policymaking processes ${ }^{2}$ towards, and the achievements of reduced burdens of undernutrition. It seeks to achieve this through four main processes: (a) information gathering and sharing; (b) explanation, justification and dialogue; $(c)$ monitoring and (d) enforcement mechanisms (Table 1$).^{3}$

Table 1: Political accountability for nutrition: key aspects

\begin{tabular}{|c|c|}
\hline Answerability & Enforcement \\
\hline $\begin{array}{l}\text { Information: the right to receive information on } \\
\text { what has been done or will be done (prompting } \\
\text { data generation) }\end{array}$ & $\begin{array}{l}\text { Incentives to reward good and punish bad performance, } \\
\text { and deter cheating on rules, promises, and } \\
\text { commitments }\end{array}$ \\
\hline
\end{tabular}

\footnotetext{
${ }^{2}$ Different types of accountability (Schedler 1999: 22/23) may focus on the 'Administrative': the expediency and procedural correctness of bureaucratic practice; on the 'Professional': ethical standards of professionalism, such as medical, academic, and judicial professionalism; on the 'Financial': State officials use public money austerely, efficiently (VFM), appropriately; on the 'Moral': Evaluate political acts on the basis of prevailing normative standards (independent of formal rules and regulations); and on the 'Legal' The observance of legal rules, including whether legislative acts are in accordance with constitutional rules. These different types of accountability gain diverse institutional expressions. For instance, responsibility for exercising both political and moral accountability applies to citizens, civil associations, mass media, and opposition parties. Specialised agencies, such as an ombudsman or anticorruption agency, are responsible for administrative and financial accountability. Ethics commissions and disciplinary courts are instituted to safeguard professional accountability, whereas judicial systems are tasked with guaranteeing legal as well as constitutional accountability.

${ }^{3}$ Schedler's key criteria of 'information' and 'monitoring mechanisms' overlap substantially with those labeled 'debate' and 'evidence' by Droop, Isenman and Mlalazi's (2008). The latter's 'ownership' criterion, like Schedler's 'incentives' and 'enforcement mechanisms' is grounded in sets of rules that guide the conduct of parties in the accountability relation. However, whereas Schedler emphasises the ability to enforce compliance, the former note the critical importance of a 'logic of participation'. Thus, within relationships of mutual accountability, the challenge is about building greater partnership, ownership and mutual responsibility that could lead to new additional commitments - perhaps somewhat contradictorily - "as much as it is to hold one another accountable" (p.5). This suggests that within the realm of international nutrition commitments, there may be place for logics of participation as well as logics of compliance.
} 


\begin{tabular}{|c|c|}
\hline $\begin{array}{l}\text { Type of nutrition information examples: } \\
\text { - Nutrition inputs (policies, finances, } \\
\text { programmes) } \\
\text { - Nutrition outputs (e.g. number of zinc } \\
\text { supplements distributed) } \\
\text { - Nutrition outcomes (e.g. stunting rate } \\
\text { reductions) }\end{array}$ & $\begin{array}{l}\text { Examples of rules: } \\
\text { - Human rights as set out in the Universal Declaration } \\
\text { of Human Rights }{ }^{4} \\
\text { - The expectation that the UK Prime Minister can be } \\
\text { trusted to deliver on his promise to put in major } \\
\text { efforts to reduce nutrition related child deaths by } \\
20 \% \text { by } 2016 \\
\text { - Countries' financial promises of support for food } \\
\text { security made at G-8 Summits, such as at l'Aquila } \\
\text { (2009), or at the N4G event in London (2013) will be } \\
\text { delivered in time } \\
\text { - The Rome Principles } 5 \text { that govern AFSI investments }\end{array}$ \\
\hline $\begin{array}{l}\text { Justification: accountable actors explain their } \\
\text { decisions and engage in public dialogues with } \\
\text { those who hold them accountable } \\
\text { - E.g. DFID consults with civil society groups on } \\
\text { its accountability strategy regarding } N_{4} G\end{array}$ & $\begin{array}{l}\text { Monitoring mechanisms prevent violation of rules, } \\
\text { promises, and commitments from going unnoticed } \\
\text { - E.g. the ONE Campaign and the US State } \\
\text { Department monitoring disbursements on Aquila } \\
\text { Food Security Initiative pledges }\end{array}$ \\
\hline & $\begin{array}{l}\text { Enforcement mechanisms and punishment in case } \\
\text { rules/promises/commitments are violated } \\
\text { - E.g.: reputational loss if the UK Prime Minister is not } \\
\text { putting in major efforts to reduce nutrition related } \\
\text { child deaths. } \\
\text { - E.g. for those CSOs who are sourcing new monies } \\
\text { from members and allocate these to combat child } \\
\text { undernutrition, the countries' aid agency provides } \\
\text { guaranteed } £ \text { for } £ \text { matched funding. }\end{array}$ \\
\hline
\end{tabular}

The informational function of accountability is to generate data and evidence for public scrutiny about the nature of the nutrition problem. The explanatory function of accountability serves to bring diverse perspectives and the voices of a plurality of stakeholders into decisionmaking processes regarding appropriate interventions towards undernutrition reduction. Monitoring mechanisms are required to ascertain the extent to which those held accountable are delivering on their nutrition promises, pledges and commitments. Monitoring thus ensures that failings and successes in this respect will not go unnoticed. Finally, monitoring links closely with enforcement mechanisms that aim to link the performance of accountable actors towards delivering improved nutrition outcomes through rewards as well as penalties. For political leadership on nutrition, this is likely to take the shape of reputational gains and losses through public exposure. However other forms of reward and punishment may be

4 Human rights can provide a platform for accountability and for empowering marginalised groups, by advocating highly consensual and value-driven principles as well as through the establishment of new normative/legislative instruments (Villar and Dodd 2005).

${ }^{5}$ AFSI investments follow the five Rome Principles of Sustainable Food Security laid out by 193 countries at the FAO-WFP-IFAD hosted Summit later that same year, to 1 ) invest in country-owned plans; 2 ) foster strategic coordination at national, regional and global levels; 3 ) strive for a comprehensive, twin-track approach to food security that consists of: a) direct action to immediately tackle hunger for the most vulnerable and b) medium and long-term sustainable agricultural, food security, nutrition and rural development programs; 4) ensure a strong role for the multilateral system; and 5) ensure sustained and substantial commitment by all partners to investment in agriculture and food security and nutrition (US Government 2012a). 
envisaged. For instance, in relations between donors and aid recipients, serious underperformance of the latter may result in suspension or termination of financial aid, whereas excellent performance may result in greater funding streams.

Putting in place accountability mechanisms can thus help to achieve multiple objectives. Informed publics and reasoned debate will bring greater attention; stimulate learning, better and more timely action; and contribute to generating greater public commitment to act on nutrition. Furthermore, the monitoring and enforcement functions of accountability provide mechanisms and incentives to sustain the momentum of commitment to address nutrition.

\subsection{An overview of nutrition commitments made in international forums}

2013 stood out as a year within which nutrition featured prominently in international development agendas, resulting in the various new public commitments announced in international forums. However, other recent commitments set out in preceding years are also worthy of discussion.

Hence, at the global level, major commitments to enhance nutrition include:

\section{Millennium Development Goals (MDGs)}

While the search for development goals post 2015 is ongoing, the current MDGs, established at the 2005 World Summit in New York remain in place. Governments, donors and international bodies set out commitments to Eradicate Extreme Hunger and Poverty under MDG Goal 1, with a specific target (1C) to halve, between 1990 and 2015, the proportion of people who suffer from hunger. At a high-level event at the UN Headquarters on 25 September 2008, governments, foundations, businesses and civil society groups rallied around the call to slash poverty, hunger and disease by 2015 , by announcing new commitments to meet the Millennium Development Goals. This gathering generated an estimated \$16 billion, including some $\$ 1.6$ billion to bolster food security (http://www.un.org/millenniumgoals/bkgd.shtml). A follow up 2010 Summit on the MDGs resulted in the Global Strategy for Women's and Children's Health.

\section{Every Woman Every Child (EWEC)}

The UN Secretary-General's Global Strategy for Women's and Children's Health, Every Woman Every Child (EWEC), aims to mobilise global action to improve the health of women and children around the world. This broad goal explicitly includes nutrition aspects. EWEC works with leaders from governments, multilateral organisations, the private sector and civil society, ${ }^{6}$ and focuses on the 75 countries which together account for more than 95 per cent of all maternal and child deaths in the world. EWEC aims to protect 88 million children from stunting, save the lives of 16 million women and children by 2015 and improve the lives of millions more. Over 260 partners have made commitments in

\footnotetext{
${ }^{6}$ Members include the Executive Office of the UN Secretary-General, national and international nongovernmental organizations, WHO, UNFPA, UNICEF, H4+, ITU, OECD, African Union, PMNCH, UN Foundation, World Bank, Countdown to 2015, Health Metrics Network, Inter-Parliamentary Union, CDC, Norad, USAID, IHP+, mHealth Alliance, University of Aberdeen, London School of Hygiene and Tropical Medicine, and the Bill and Melinda Gates Foundation, among others (iERG 2012).
} 
various forms (financial, policy, advocacy, innovation, monitoring and evaluation, etc.), including financial commitments to the tune of $\$ 40$ billion made in September 2010. Many commitments aim to accelerate action towards the achievement of MDG 4 (reduce child mortality) and MDG 5 (improve maternal health) and to contribute to the overall goals (http://www.everywomaneverychild.org/commitments).

\section{World Health Assembly targets}

In May 2012, the World Health Assembly (WHA), the decision-making body of the World Health Organisation (WHO), agreed on a new target: reducing the number of stunted children under the age of five by 40 per cent by 2025 .

\section{Nutrition for Growth}

In June 2013, the Nutrition for Growth $\left(\mathrm{N}_{4} \mathrm{G}\right)$ summit organised by the UK and Brazilian Governments brought together governments, businesses, UN agencies, CSOs and scientific institutions, which all made commitments to do more to tackle undernutrition. These commitments are captured in the Nutrition for Growth Compact and in the accompanying Commitments Document. The collective ambition of those who committed was to:

- Ensure that at least 500 million pregnant women and children under two are reached with effective nutrition interventions.

- Prevent at least 20 million children under five from being stunted.

- Save at least 1.7 million lives by reducing stunting, increasing breastfeeding, and through the treatment of severe acute malnutrition.

(Anon 2013)

The event secured new commitments of up to $f 2.7$ billion ( $\$ 4.15$ billion) to tackle undernutrition up to 2020 , \pm 1.9 billion ( $\$ 2.9$ billion) of which is core funding with the remainder secured through matched funding. The UK committed an additional $£ 375$ million of core funding and $£ 280$ million of matched funding from 2013 to 2020 (UK Government 2013).

\section{European Union}

During the $\mathrm{N}_{4} \mathrm{G}$ Conference in London, EU Commissioner Piebalgs announced the commitment to support partner countries in reducing stunting in children under five. The EU aims to contribute to 10 per cent of the WHA targets on stunting reduction, by at least seven million in 2025. It was accompanied by the pledge to allocate $€ 3.5$ billion during the $2014-2020$ programming period to attain the EU's stunting target.

\section{Zero Hunger Challenge}

Launched in June 2012, the Zero Hunger Challenge, proposed by UN Secretary-General Ban Ki-Moon asserts an ambitious commitment to ensure 100 per cent access to adequate food all year round, zero stunted children under two years of age, to ensure sustainability of all food systems, 100 per cent increase in smallholder productivity and income, and zero loss or waste of food (UN 2012). A raft of 
country groupings, including the G77+China, Least Developed Countries, and the EU explicitly endorsed the Zero Hunger Challenge at the $67^{\text {th }}$ UN General Assembly. It has been adopted by the 23 multilateral organisations that make up the High Level Task Force for Global Food Security.

\section{Food Assistance Convention}

The Food Assistance Convention (FAC) is an international development treaty designed to ensure that minimum levels of food are made available to help meet the emergency food needs of developing countries. Each Party to the Convention makes a minimum annual financial commitment of the level of food assistance they will support (in kind). The FAC replaces the previous Food Aid Convention (1999). The new FAC includes a broader toolbox of activities and products to capture a wider variety of food assistance interventions, including nutrition, and underscores the importance of not only the quantity of food, but also the quality. The FAC entered into Force on January 1, 2013. To date, of 14 signatories (13 countries and the EU) to the FAC at the end of December last year, eight had deposited instruments of ratification, acceptance or approval: Austria, Canada, Denmark, EU, Finland, Japan, Switzerland and the US (http://foodassistanceconvention.org).

\section{New Alliance for Food Security and Nutrition}

The New Alliance emerged from the G-8 Camp David summit in May 2012 to establish a public private partnership between governments, private sector and international donors and multilateral agencies. It aims to increase domestic and foreign private investments in African agriculture, take innovations that can enhance agricultural productivity to scale, and reduce the risk borne by vulnerable economies and communities. The Alliance aims to achieve sustained and inclusive agricultural growth and raise 50 million people out of poverty over the next ten years (US Government 2012b; http://iif.un.org/content/new-alliance-food-security-and-nutrition\#sthash.3klorCeU.hyB4nioh.dpuf). The New Alliance has been framed as 'additive' and complementary to the L'Aquila commitments (see below), and represents a renewed focus on private sector approaches to achieving food security (ONE Campaign 2012). To improve nutritional outcomes and reduce child stunting, the G-8 members committed to (US Government 2012b):

- Actively support the SUN movement;

- Maintain robust programs to further reduce child stunting;

- Improve tracking and disbursements for nutrition across sectors and ensure coordination of nutrition activities across sectors;

- It will further support the accelerated release, adoption and consumption of bio-fortified crop varieties, crop diversification, and related technologies to improve the nutritional quality of food in Africa, and develop a nutrition policy research agenda and support the efforts of African institutions, civil society and private sector partners to establish regional nutritional learning centers

\section{L'Aquila Food Security Initiative (AFSI)}


In 2009, during the L'Aquila Summit, the G-8 and other donors collectively pledged more than $\$ 22$ billion over three years to ensure a comprehensive strategy focused on sustainable agriculture development. It initiated the L'Aquila Food Security Initiative, with a founding mandate to focus on accountability and to ensure follow through on the commitments made.

\section{InterAction}

On the sidelines of the UN General Assembly in September, InterAction, an alliance of 198 U.S. based civil society organisations, pledged more than $\$ 1$ billion in private, nongovernment funding for 20122015 to improve food security and nutrition worldwide (US Government 2012a). ${ }^{7}$

\section{International commitments: who is accountable, to whom?}

The discussion of commitments above shows that accountability relations are characterised by a substantial variety of nutrition actors (donor and aid receiving governments, CSOs, private companies) each having distinct principals that they are accountable to. This produces a fairly ill-defined patchwork of accountability relations (Table 2), some being more strongly pronounced than others. It should be noted that were these actors formally sign up to international nutrition commitments, this generates a new set of accountability relationships, additional to those set out in Table 2.

Table 2: Institutional actors making international nutrition commitments: who is accountable, to whom?

\begin{tabular}{|l|l|l|}
\hline Actors (Agent) & Accountable to whom (Principal) \\
\hline $\begin{array}{l}\text { Developing country } \\
\text { governments }\end{array}$ & $\begin{array}{l}\text { Domestic citizens, } \\
\text { communities including through } \\
\text { parliament }\end{array}$ & $\begin{array}{l}\text { Donors in case of aid relationships in } \\
\text { spirit of mutual accountability }\end{array}$ \\
\hline Multilateral financing agencies & Donor countries & - \\
\hline UN Agencies & $\begin{array}{l}\text { UN General Secretary and } \\
\text { General Assembly }\end{array}$ & Donors in case of aid relationships \\
\hline Bilateral donors & $\begin{array}{l}\text { Domestic citizens in donor } \\
\text { countries including through } \\
\text { parliament }\end{array}$ & $\begin{array}{l}\text { Developing country governments in } \\
\text { spirit of mutual accountability }\end{array}$ \\
\hline INGOs & Donating members, funders & $\begin{array}{l}\text { Citizens, communities and governments } \\
\text { in countries in which they operate, and } \\
\text { in which they have domicile }\end{array}$ \\
\hline Civil society organisations & Donating members, funders & $\begin{array}{l}\text { Citizens, communities and governments } \\
\text { in countries in which they operate }\end{array}$ \\
\hline Private sector businesses & $\begin{array}{l}\text { Owners, shareholders, } \\
\text { customers }\end{array}$ & $\begin{array}{l}\text { Citizens, communities and governments } \\
\text { in countries in which they operate, and } \\
\text { in which they have domicile }\end{array}$ \\
\hline
\end{tabular}

7 World Vision, Heifer International, Catholic Relief Services, Save the Children and ChildFund International have pledged to invest more than $\$ 900$ million in this effort (http://www.interaction.org/sites/default/files/og.27.2012\%20Member\%2olmpact\%200n\%20Hunger\%20\%20Final.docx_pdf). 


\begin{tabular}{|l|l|l|}
\hline $\begin{array}{l}\text { Foundations, philanthropic } \\
\text { organisations }\end{array}$ & $\begin{array}{l}\text { Private individuals and } \\
\text { governing boards }\end{array}$ & - \\
\hline
\end{tabular}

As nutrition commitments proliferate, the patchwork is mended regularly, reflecting that international public nutrition commitments are often made in as yet weakly institutionalised environments, within which it is unclear who exactly holds whom to account for what, by when, how and in accordance to what rules and norms.

Whereas Parliaments could in principle assert a mandate to critically review their governments on their performance delivering on nutrition commitments, in practice this often does not happen in a structured manner. International aid effectiveness campaigns, such as the Paris Principles and Accra Action Agenda on Aid Effectiveness (2008), and the Busan Partnership for Effective Development Cooperation (2011) promote relationships of mutual accountability between donors and recipient countries. This seeks to enhance transparency in the use of development resources, to strengthen public support for national policies and development assistance. ${ }^{8}$ For aid recipients, they seek to (a) strengthen as appropriate the parliamentary role in national development strategies and/or budgets and (b) reinforce participatory approaches by systematically involving a broad range of development partners when formulating and assessing progress in implementing national development strategies. Donors commit, in turn, to provide timely, transparent and comprehensive information on aid flows so as to enable partner authorities to present comprehensive budget reports to their legislatures and citizens. Both partner countries and donors further commit to jointly assess mutual progress in implementing agreed commitments on aid effectiveness.

In practice, mutual accountability may not always fit the Accra and Busan principles quite as well. Where legal and democratic avenues of compliance are non-existing or weak, such as in arms control, disarmament, or cooperation on international environmental issues (e.g. Kyoto Protocol), mutual accountability often involves a stronger 'logic of participation' than 'logic of compliance' (Droop et al, 2008). Particularly as there is usually no single over-arching authority to monitor and enforce good behaviour, and as the level of commitment and ownership also varies between participants, maintaining participation and gradually building further commitment through a process of contestation and deliberation is seen as a more feasible approach. The challenge is hence to build commitment, mutual responsibility, ownership and partnership, as much as it is to hold one another accountable.

Nevertheless, examples of approaches that do incorporate a clear logic of compliance can also be found within the realm of international development, as will be shown in section 1.3.

Before we move on exploring the key focus of this paper, that is how accountability elements such as information, evidence, dialogue, monitoring and enforcement are given shape in respect of the various international commitments on nutrition, we briefly touch on a related matter. Delivering on international commitments will require additional efforts by the various nutrition actors that signed up. Pledges and promises need to be turned into programmatic and policy activities and in delivery of nutrition services. Their effectiveness and success will depend on accountability mechanisms at national and subnational level that while feeding in to the accountability mechanisms set up for the international

\footnotetext{
${ }^{8}$ At the World Summit on Food Security 2009, donors agreed to the Rome Principles, a series of new commitments to improve aid effectiveness in agriculture and food security.
} 
commitments, are quite distinct. While their detailed discussion is beyond the scope of this paper, we briefly discuss aspects of accountability for such nutrition services and policy interventions.

\section{Accountability for nutrition services}

The influential World Development Report 2004 sets out that strong accountability relationships especially between decision makers, service providers and clients - are key to the better performance of public service provision. It links the public with service providers through a short and a long route. The short route concerns the need for (nutrition) service providers to report to their clients. The long route refers to how service providers report to senior bureaucrats, who themselves are accountable to democratically elected leaders, who in turn are accountable to the electorate.

Various mechanisms support short and long routes to accountability between individuals and collectives in their capacity as citizens, and individuals in their capacity as public (state) officials. Licensing and accreditation (of physicians, nurses, nutritionists); public financing that link central government contributions to the amount and quality of services provided by local governments; and quality assurance policies, standards and benchmarks can all contribute to accountability of service providers and help to improve the quality of care and client satisfaction in nutrition services. Moreover, within organisations or bureaucracies, subordinate officials (agents) are held to account for their performance by superiors (principals). Principal-agent relationships are an important institutional feature that citizens can sometimes successfully exploit (Gupta 2012) to make low level officials (indirectly) more accountable to them and to offer some level of check on excessive use of discretion in the application of (nutrition) policies, programmes and rules. Furthermore, the state comprises a wide range of bodies and agencies, between which accountability mechanisms exist. Montesquieu's classic checks and balances between the legislative, executive and judicial wings of state aim to achieve accountability and a check on the unbridled exercise of power. Moreover, diverse agencies may exercise 'horizontal' forms of accountability within these wings of the state. Critically, this means that the state offers a wide range of potential forums that citizens or advocacy coalitions can target as allies for holding other government bodies to account.

In theory and sometimes in practice, market mechanisms can also introduce elements of performance accountability (between service providers and customers), e.g. by introducing competition between service providers on the basis of performance information made public (Brinkerhoff 2004). Finally, anthropological studies suggest looking beyond principal-agent relationships, and formal social and professional norms, to the informal and practical norms that govern (nutrition) service delivery. Actual service delivery may be governed by institutionalised practical (social and professional) norms that operate side by side or actively violate formal professional or social norms, and that have their own logic of accountability. For instance, the poor nursing care practices in African hospitals for impoverished elderly people can only be explained by such institutionalised practical norms, because they routinely violate professional norms (i.e. the Hippocratic oath), official organisational norms (hospitals' declaration of care responsibilities) and otherwise common social norms (respect for the elderly) (Olivier de Sardan 2008).

Following this brief discussion of accountability for nutrition services and policy interventions, the next section returns to information, evidence, dialogue, monitoring and enforcement aspects in the various international commitments on nutrition, as presented above in Table 1. Sections 1.2 and 1.3 address answerability aspects of current nutrition accountability arrangements, by looking at what type of 


\section{IL CHILDREN'S \\ INVESTMENT FUND \\ FOUNDATION}

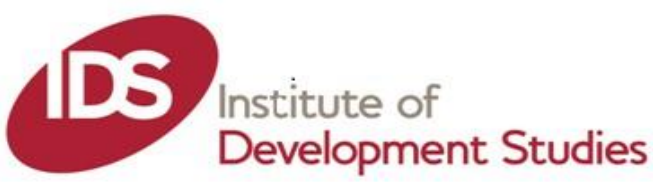

nutrition information is currently used for accountability purposes, who is involved in monitoring to hold which actors to account, and with what kind of incentives and enforcement systems? Section 1.4 identifies major gaps, and 1.5 offers suggestions on what may be done to address these. 


\subsection{Answerability for nutrition: information and evidence}

The informational function of accountability is to generate data and evidence for public scrutiny about the nature of the nutrition problem. This section presents a brief discussion of the kind of nutrition data that may be desirable generating or collating to allow for greater accountability for international nutrition commitments. It looks at three aspects: nutrition outcome data; nutrition output data; nutrition input data. Unless otherwise specified, the focus here is on the public sector. As there are potentially numerous indicators for nutrition inputs, outputs and outcomes, the discussion below offers illustrative examples, but does not aim to be exhaustive.

\section{Nutrition outcome data}

The chief purpose of this data is to provide insights into the current nutritional status for targeted groups (notably children) and in trends (progress/regress) in nutrition outcomes and hence potentially allows for tracking progress towards those international nutrition commitment that explicitly identify quantitative targets. However, major anthropometric indicators for child undernutrition outcomes are measured insufficiently frequently to adequately inform public policy. In many high burden countries, stunting (height for age), wasting (weight for height) and undernourishment (weight for age) data are collected through statistically representative nutrition surveys at best every three to five years, and often less frequently. Various parties are now experimenting with methodological innovations employing real time monitoring techniques and mobile phone technology. While offering promise, right now real time monitoring techniques are largely untested (Barnett et al. 2013) and the jury remains out as to whether they yet offer a serious methodological and practical alternative to current nutrition outcome monitoring approaches.

\section{Nutrition input data}

Nutrition input data can reflect efforts that governments make to address nutrition issues, and are based on the assumption that these efforts contribute to improved nutrition outcomes either through direct and indirect interventions, or through creating enabling environments (Gillespie, Haddad et al. 2013). Government inputs can take the shape of financial, policy and legal instruments, and the development of adequate capacity to deliver these (by the public, private or third sector). Assessing these inputs can potentially be done using a wide range of indicators. Here we offer a few suggestions.

Basic financial indicators would give insight in the budget allocation patterns supporting nutrition policies and programmes, and would show actual budget spending. More advanced indicators could include aspects of, for instance, cost efficiency and cost effectiveness, and the relative financial contributions made by governments (through general taxation, or social insurance mechanisms) and donors. Basic indicators on policy could note the existence, and key features of direct nutrition policies (e.g. vitamin A supplementation), indirect nutrition policies (e.g. child grants) and policies that constitute important enabling environments for achieving enhanced nutrition outcomes (e.g. equal economic rights for women and men enshrined in law and effectively exercised in practice). 
Indicators could also focus on substantive policy elements: e.g. time bound targets; priorities for action etc., and could take note whether or not explanations and justifications are provided for the policy choices made (for instance in making policy documents easily accessible), thus enabling public scrutiny and debate about assumptions underlying nutrition policy. Moreover, because public policies are only as good as they are delivered, data on the quality of nutrition policy implementation would be very important. This may take the shape of administrative data, for instance on the policy outputs produced, or impacts (wherever these could be established with rigour). Such administrative data could well be triangulated by taking account of the subjective experience of these policies by actual beneficiaries and by those beneficiaries who are supposed to benefit, but for one reason or another are not (exclusion error).

Finally, as regulatory frameworks and enforcement mechanisms will remain ineffective in the absence of institutional capacity to implement these, input data on the capacity to deliver key nutrition interventions could be valuable. For instance, by setting out the number of (additional) nutrition staff recruited, their education qualifications, or indicators regarding the availability of physical infrastructure at subnational (district/province/etc) level for implementing nutrition programmes.

While private sector companies have a critical role to play in food systems that make affordable nutritious food accessible to the poor, and increasingly are signed up partners in international nutrition commitments such as the New Alliance, as yet, data on their contributions are weakly developed. New data forms need to be developed that can give clear insight in nutrition inputs and output contributions, but that also strike a meaningful balance between commercial confidentiality and public accountability interests, that can drive greater commitments in future.

Similarly, where international NGOs or alliances of civil society groups sign up to international nutrition commitments, they are to be held accountable for their performance. Some groups such as WorldVision and Interaction have now started to self-report on their delivery on EWEC and Nutrition for Growth commitments (see section 1.4).

\section{Nutrition output data}

Nutrition output data show the outputs produced as a result of nutrition inputs. They may contribute to a picture of how policies and programmes are implemented, and may suggest (but not prove) the likely success or failure of programmes to establish enhanced nutrition outcomes. For instance, output indicators may report on the number of latrines built for sanitation purposes, or on the beneficiaries who received Vitamin A supplements in absolute (e.g. one million children) or relative terms (e.g. a coverage rate of 90 per cent of children between 6-59 months of age). Finally, in a range of countries, legal efforts have been made to enshrine citizens' right to food into legislation and to put in place legal instruments advancing food and nutrition security outcomes, such as enshrining the International Code of Marketing of Breastmilk Substitutes (ICMBS) into domestic law.

While data on such input indicators is now being collected, arguably these need to be complemented with a set of related output indicators that comment on the quality, enforcement and justiciability of such laws and rights. For instance, with regards the ICMBS, output indicators with higher resolution could include the number of violations registered, court cases commenced and completed, and the number of convictions. 


\subsection{Monitoring mechanisms and means of dialogue}

Having discussed potential nutrition outcome, input and output indicators that may be part of accountability initiatives, this section considers which indicators are currently being monitored, by whom, and what kind of mechanisms are being used supporting aspects of answerability, justification and dialogue. We find that the various commitments are using a range of monitoring mechanisms that contain some form of explanation, justification and dialogue between accountable parties and those holding them to account. These mechanisms include public reports, annually or otherwise, statistics on key progress indicators delivering these commitments, resolutions by governing bodies such as the World Health Assembly, and findings from evaluation platforms.

\subsubsection{Monitoring global nutrition commitments}

\section{Millennium Development Goals (MDGs)}

Country-led monitoring and evaluation systems have been critical to assessing progress towards achieving the MDGs, which have fed into globally established databases to monitor the MDGs, such as DevInfo and ChildInfo. Besides UN Agencies, regional agencies (CEPAL, CEDLAS, ESCAP and Eurostat) and various development banks routinely monitor performance on MDGs. For instance, in Latin America, CEPAL and the World Bank's Latin America Country (LAC) group monitor MDG Goal 1 progress (on poverty reduction and hunger). These agencies use household surveys to develop their own poverty measures, or assess the quality of national statistical agency poverty estimates. These regional agencies often provide a second or third source of expert opinion for explaining inconsistencies in national and global monitoring of poverty (McLeod 2007).

\section{Every Woman Every Child (EWEC)}

EWEC provides a good example of how to integrally develop new institutional mechanisms to monitor and foster greater accountability towards commitments at both international and national levels. As part of EWEC, a Commission on Information and Accountability for Women's and Children's Health was established, which in May 2012 presented 10 recommendations to improve accountability in countries and globally. An international Expert Review Group was then established to:

- Assess the extent to which all stakeholders honour their commitments to the Global Strategy and the Commission, including the United States' $\$ 40$ billion of financial commitments;

- Review progress in implementation of the recommendations of the Commission;

- Assess progress towards greater transparency in the flow of resources and achieving results;

- Identify obstacles to implementing both the Global Strategy and the Commission's recommendations;

- Identify good practice, including in policy and service delivery, accountability arrangements and value-for-money approaches relating to the health of women and children and

- Make publicly accessible recommendations to improve the effectiveness of the accountability framework developed by the Commission (http://www.who.int/woman_child_accountability/ierg/en/). 
Subsequently, country accountability frameworks (CAFs) have been developed to guide implementation of aspects of the global strategy, combining country assessments and (costed) roadmaps. The approach towards developing the CAFs are framed around the broad health goals of the Strategy, and thus contain distinct aspects that are of immediate relevance to nutrition, often under the banner of Maternal, Neonatal and Child Health (MNCH), such as action towards improving civil registration systems.

Countdown to 2015 has also taken on a role in ensuring accountability for fulfilment of these commitments. It annually reports on coverage, equity, health systems, health policies and financing indicators (World Health Organization and UNICEF 2013).

\section{World Health Assembly targets}

In order to achieve the WHA child stunting target, the World Health Assembly (WHA) has endorsed a comprehensive draft implementation plan on maternal, infant and young child nutrition and called on member states to translate this into national policy and law. This plan contains a set of global nutrition targets (http://www.who.int/pmnch/media/events/2013/au_policy brief_nu).

The WHO Executive Board reports on an annual basis to the WHA on the implementation progress of this plan, and also reports on the implementation of the International Code of Marketing of Breast-milk Substitutes and related Health Assembly resolutions (WHO 2012b). Member states are urged to implement the recommendations provided by the Commission on Information and Accountability for Women's and Children's Health to improve the accountability of results and resources by:

(1) Strengthening the accountability mechanisms for health in their own countries;

(2) Strengthening their capacity to monitor, including utilising local evidence, and evaluating progress to improve their own performance;

(3) Contributing to the strengthening and harmonisation of existing international mechanisms to track progress on all commitments made.

\section{Nutrition for Growth}

A number of steps are being developed to track individual commitments made at the 2013 Nutrition for Growth Summit, also aiming to embed these commitments within the SUN monitoring and evaluation process. Tentatively, these include:

- Inviting each of the respective SUN networks to take responsibility for tracking the commitments made by their constituent members in a consistent, comparable manner. The source of data for tracking the commitment will also be agreed.

- SUN countries will report their progress periodically to the SUN Secretariat through the SUN Monitoring and Evaluation (M\&E) framework.

- If needed, the UK will help support the respective networks to ensure that the data can be effectively gathered by helping to support a technical assistance facility to draw down on. 
- The monitoring data will be reviewed by the consortium producing a Global Nutrition Report and compiled in an annex of the report, ideally using a simple traffic light system to determine commitments which are off track, on track or delivered.

(Anon 2013)

The World Bank's (WB) N4G commitment on nutrition includes to increase the share of agriculture projects with an explicit focus on nutrition (currently at 12 per cent). This commitment was already set out in its Agricultural Action Plan FY13-15. The Bank annually conducts an ex post portfolio analysis, and identifies the number of projects funded having an explicit mention of the nutrition sensitive aspects of agricultural production and marketing in agricultural projects as a share of all agricultural projects. Internally, this ratio is reported to the board (as part of the reporting on the Agricultural Action Plan). Regional WB managers decide on whether or not to adopt nutrition sensitive agricultural investments.

\section{European Union}

The EU Communication 'Enhancing Maternal and Children Nutrition in external assistance: an EU policy framework' was adopted by the European Commission on the 12th March 2013. It sets out strategic priorities to achieve its aims of reducing the number of under-fives suffering from stunting and wasting. The Commission is drafting an Action Plan on nutrition which outlines in detail how the Commission plans to reach its commitment to reducing stunting, and towards helping to deliver WHA and $\mathrm{N}_{4} \mathrm{G}$ targets. The Action Plan will address how strategic objectives are to be attained, as well as detailing the accountability framework, looking at resource tracking and measurement of impact. The Action Plan is expected to be ready by the first half of 2014 (European Commission 2013). Furthermore, at the time of writing (February 2014), consultations are ongoing on how to develop National Evaluation Platforms and integrated Nutrition Information Systems

\section{Zero Hunger Challenge}

The Zero Hunger Challenge did not set a deadline for achieving its ambitious aims (Ford 2012), so the Challenge may perhaps be better understood as a statement of ambition than as an actual accountable commitment. Yet, fragmented monitoring efforts are made at global, regional and national level, including recommendations by the UN Secretary-General's Food Security Task Force for a 'faster and more precise' way of measuring hunger and food insecurity that is to be tested by the Food and Agriculture Organization of the United Nations (FAO). Moreover, an independent and global Community for Zero Hunger was launched to support, and monitor the UN Zero Hunger Challenge (http://www.zerohungercommunity.org/).

In a few countries, e.g. in Barbados and Antigua, a Plan of Action 2013-2014 has been jointly prepared by the Government and collaborating agencies (FAO, IICA, PAHO, PMA, ECLAC), inspired by the Zero Hunger Challenge (Government of Antigua and Barbuda 2013). It uses a multi-stakeholder dialogue, and a M\&E Platform ${ }^{9}$ has been set up to assess progress regarding Action Plan objectives. At the regional level, the Asia-Pacific Zero Hunger Challenge was launched in April 2013.

${ }^{9}$ http://www.mezhcab.org/ 


\section{Food Assistance Convention}

The FAC tracks the value or quantity commitment of food aid commodities, cash and vouchers and nutritional interventions. After each calendar year, the Parties report their food assistance operations, detailing how they meet their respective commitments, including specific reporting on support for nutrition interventions. The FAC Secretariat produces a report each year (beginning in 2014) that will list the Eligible Activities or Eligible Products that each Party provided in order to meet their commitment. The report will include specific reporting on nutrition. The first report will be available from the Secretariat on June 30, 2014, and on an annual basis thereafter. The Rules of Procedure and Implementation of the Food Assistance Convention (2012) do neither set out what rules govern the effective delivery of commitments nor set out any enforcement mechanisms (http://www.foodassistanceconvention.org/convention/RulesofProcedure.pdf).

\section{New Alliance for Food Security and Nutrition}

In order to achieve the commitments set out by the New Alliance, Cooperation Frameworks to implement the New Alliance have been created for six countries: Ghana, Ethiopia, Tanzania, Cote D'Ivoire, Burkina Faso, and Mozambique (US Government 2012b).

\section{L'Aquila Food Security Initiative (AFSI)}

An internal AFSI working group has monitored disbursements towards financial commitments made in 2008. By 2012, AFSI donors reported on a substantial portion of each donor's investments in food security investments in a subset of developing countries. They rightly argued that making tables with disbursements vs commitments publicly available was a meaningful step toward increasing accountability and the transparency of G-8 commitments (US Government 2012a). However, it should be noted that this only happened towards the end of the AFSI period. In the meanwhile, external actors such as the ONE Campaign tried to monitor the delivery of AFSI commitments, to be highly critical of the opacity concerning the additionality of these commitments to ODA. It emerged that about only one third ( $\$ 6.8$ billion) of the $\$ 22$ billion pledged involved new resources, additional to previously planned expenditures. This amount was highly similar to the $\$ 6.7$ billion which was not disbursed by 2012 ; as affirmed by an AFSI working group which assessed that 67 per cent of the total commitment was disbursed. Canada, Italy, the Netherlands, Russia, Spain, Sweden, and the United Kingdom had fully disbursed their commitments (http://iif.un.org/content/laquila-food-securityinitiative\#sthash.3GF4wOva.dpuf; US Government 2012a).

\section{InterAction}

Starting in 2013, InterAction (2012b) is now making annual reports at the UN General Assembly on disbursements towards its 1 billion dollar funding commitment towards addressing nutrition and food insecurity.

Table 4 provides an overview of commitments and current monitoring arrangements. 
Table 4: Monitoring nutrition commitments

\begin{tabular}{|c|c|c|c|c|}
\hline $\begin{array}{l}\text { Who } \\
\text { commits? }\end{array}$ & Which commitment? & Who monitors? & What? & How? \\
\hline EWEC & $\begin{array}{l}\text { Saving } 16 \text { million lives by } \\
2015, \text { protecting } 88 \text { million } \\
\text { children from stunting, } \\
\text { advancing the control of } \\
\text { deadly diseases such as } \\
\text { malaria, HIV/AIDS, and } \\
\text { ensuring access for women } \\
\text { and children to quality } \\
\text { facilities and skilled health } \\
\text { workers } \\
\text { Financial commitments of } \\
\text { US } \$ 40 \text { billion made in } \\
\text { September } 2010\end{array}$ & $\begin{array}{l}\text { International } \\
\text { Expert Review } \\
\text { Group (iERG) } \\
\text { Countdown to } \\
2015 \\
\text { WHA }\end{array}$ & $\begin{array}{l}\text { iERG } \\
\text { assesses the } \\
\text { extent to } \\
\text { which } \\
\text { stakeholders } \\
\text { honour their } \\
\text { commitmen } \\
\text { ts to the } \\
\text { Global } \\
\text { Strategy } \\
\text { and the } \\
\text { Commission } \\
\text {; inc. the } \\
\text { US } \$ 40 \\
\text { billion of } \\
\text { commitmen } \\
\text { ts }\end{array}$ & $\begin{array}{l}\text { iERG Reports annually to the } \\
\text { UN-GA through WHO's } \\
\text { Director-General. The } \\
\text { Commission on Information } \\
\text { and Accountability for } \\
\text { Women's and Children's Health } \\
\text { proposed a set of core } \\
\text { indicators for monitoring } \\
\text { country progress towards its } \\
\text { recommendations. WHA } \\
\text { resolutions comment on } \\
\text { progress and encourage } \\
\text { member states to implement }\end{array}$ \\
\hline $\begin{array}{l}\text { World } \\
\text { Health } \\
\text { Assembly }\end{array}$ & $\begin{array}{l}\text { Reducing the number of } \\
\text { stunted children under the } \\
\text { age of } 5 \text { by } 40 \text { per cent by } \\
2025\end{array}$ & $\begin{array}{l}\text { WHO Executive } \\
\text { Board }\end{array}$ & $\begin{array}{l}\text { Member } \\
\text { States } \\
\text { monitor and } \\
\text { evaluate } \\
\text { their policies } \\
\text { and } \\
\text { programme } \\
\text { s, with } \\
\text { support } \\
\text { from WHO }\end{array}$ & $\begin{array}{l}\text { Member States periodically } \\
\text { report to WHA on } \\
\text { implementation status of } \\
\text { resolution }\end{array}$ \\
\hline $\mathrm{N}_{4} \mathrm{G}$ & $\begin{array}{l}\text { Prevent at least } 20 \text { million } \\
\text { children under } 5 \text { from being } \\
\text { stunted. Save at least } 1.7 \\
\text { million lives by reducing } \\
\text { stunting, by increasing } \\
\text { breastfeeding, and through } \\
\text { the treatment of severe } \\
\text { acute malnutrition. Ensure } \\
\text { that at least } 500 \text { million } \\
\text { pregnant women and } \\
\text { children under two are } \\
\text { reached with effective } \\
\text { nutrition interventions. } \\
\text { Financial pledges } \\
\text { exceeding } \$ 25 \text { billion }\end{array}$ & $\begin{array}{l}\text { Mechanism } \\
\text { under } \\
\text { development, } \\
\text { tentatively } \\
\text { involves SUN } \\
\text { networks, SUN } \\
\text { Secretariat }\end{array}$ & $\begin{array}{l}\text { Group of } \\
\text { core } \\
\text { partners, } \\
\text { chaired by } \\
\text { UK govt to } \\
\text { lead. Close } \\
\text { cooperation } \\
\text { with SUN } \\
\text { Lead Group. } \\
\text { UK and } \\
\text { Brazil } \\
\text { ministers } \\
\text { review }\end{array}$ & Annual Global Progress reports \\
\hline
\end{tabular}




\begin{tabular}{|c|c|c|c|c|}
\hline EU & $\begin{array}{l}\text { Support partner countries } \\
\text { to reduce stunting by } 7 \\
\text { million children under } 5 \\
\text { between } 2014-2020 \text { ( } 10 \% \\
\text { of WHA target). Also to } \\
\text { contribute to WHA target } \\
\text { to reduce the number of } \\
\text { children under } 5 \text { who are } \\
\text { wasted } \\
\text { A pledge to allocate } € 3.5 \\
\text { Billion during the } 2014^{-} \\
2020 \text { programming period } \\
\text { to attain the EU's stunting } \\
\text { target }\end{array}$ & $\begin{array}{l}\text { European } \\
\text { Commission } \\
\text { (Commissioner } \\
\text { Piebalgs) }\end{array}$ & $\begin{array}{l}\text { The } \\
\text { performanc } \\
\text { e of EU } \\
\text { investments } \\
\text { in nutrition } \\
\text { in } 9 \text { African } \\
\text { countries } \\
\text { The extent } \\
\text { to which } 3 \\
\text { strategic } \\
\text { objectives } \\
\text { are achieved }\end{array}$ & $\begin{array}{l}\text { Country Cooperation } \\
\text { Frameworks with } 9 \text { African } \\
\text { countries }^{10} \text { set specific nutrition } \\
\text { objectives and targets up to } \\
2022 \\
\text { The EC is drafting an Action } \\
\text { Plan on nutrition (release: 2014) } \\
\text { which outlines in detail how to } \\
\text { reach its commitments, inc. an } \\
\text { accountability framework that } \\
\text { looks at resource tracking and } \\
\text { measurement of impact } \\
\text { Consultations on NEPN/NIS are } \\
\text { ongoing. }\end{array}$ \\
\hline InterAction & $\begin{array}{l}\text { Collective of US based } \\
\text { pledged } \$ 1 \text { billion for food } \\
\text { security and nutrition }\end{array}$ & $\begin{array}{l}\text { No specific } \\
\text { body, the } \\
\text { general public }\end{array}$ & $\begin{array}{l}\text { On financial } \\
\text { disburseme } \\
\text { nts vs } \\
\text { pledges }\end{array}$ & $\begin{array}{l}\text { InterAction presents annual } \\
\text { reports on pledges and } \\
\text { disbursements at UN-GA, } \\
\text { starting in } 2014\end{array}$ \\
\hline $\begin{array}{l}\text { Zero } \\
\text { Hunger } \\
\text { Challenge }\end{array}$ & $\begin{array}{l}\text { 1. } 100 \% \text { access to adequate } \\
\text { food all year round. } 2 \text {. Zero } \\
\text { stunted children less than } 2 \\
\text { years. } 3 \text {. All food systems } \\
\text { are sustainable. } 4.100 \% \\
\text { increase in smallholder } \\
\text { productivity and income } 5 . \\
\text { Zero loss or waste of food }\end{array}$ & $\begin{array}{l}\text { UN Secretary } \\
\text { General overall, } \\
\text { with support } \\
\text { from regional } \\
\text { (e.g. ESCAP) } \\
\text { and nationally } \\
\text { determined } \\
\text { mechanisms } \\
\text { At global level: } \\
\text { Community for } \\
\text { Zero Hunger }\end{array}$ & $\begin{array}{l}\text { Progress } \\
\text { towards } \\
\text { achieving } 5 \\
\text { global } \\
\text { objectives; } \\
\text { or against } \\
\text { nationally } \\
\text { determined } \\
\text { objectives }\end{array}$ & $\begin{array}{l}\text { e.g. in Antigua and Barbados, a } \\
\text { Monitoring and Evaluation } \\
\text { Platform assesses progress } \\
\text { towards objectives of a national } \\
\text { Action Plan }\end{array}$ \\
\hline MDGs & $\begin{array}{l}\text { MDG 1: } 50 \% \text { reduction on } \\
1990 \text { hunger levels by } 2015\end{array}$ & $\begin{array}{l}\text { UN General } \\
\text { Assembly } \\
\text { UN Statistics } \\
\text { Division MDG } \\
\text { Indicators; and } \\
\text { the MDG } \\
\text { monitor, } \\
\text { http://www.md } \\
\text { gmonitor.org; } \\
\text { the World Bank } \\
\text { (www.develop } \\
\text { mentgoals.com } \\
\text { ) }\end{array}$ & $\begin{array}{l}\text { Indicators } \\
\text { are } \\
\text { identified } \\
\text { for each of } \\
\text { the MDGs }\end{array}$ & $\begin{array}{l}\text { UN Agencies distribute } \\
\text { monitoring tasks, as per } \\
\text { UNDAFs. E.g. WHO reports to } \\
\text { WHA on annual basis (until } \\
2015 \text { ) health related MDGs } \\
4,5 \cdot{ }^{11} \text { Development banks, } \\
\text { regional agencies also monitor }\end{array}$ \\
\hline $\begin{array}{l}\text { New } \\
\text { Alliance for } \\
\text { Food }\end{array}$ & $\begin{array}{l}\text { The Alliance aims to } \\
\text { achieve sustained and } \\
\text { inclusive agricultural }\end{array}$ & $\begin{array}{l}\text { A Leadership } \\
\text { Council will } \\
\text { drive and track }\end{array}$ & $\begin{array}{l}\text { Indicators } \\
\text { unclear }\end{array}$ & $\begin{array}{l}\text { Annual reports to the G-8 and } \\
\text { African Union on progress } \\
\text { towards achieving the }\end{array}$ \\
\hline
\end{tabular}

${ }^{10}$ These concern: Benin, Malawi, Nigeria, Ethiopia, Ghana, Tanzania, Burkina Faso, Cote d'Ivoire and Mozambique (European Commission 2013)

${ }^{11}$ MDG 4 concerns child mortality, MDG 5 maternal mortality. 


\begin{tabular}{|c|c|c|c|c|}
\hline $\begin{array}{l}\text { Security } \\
\text { and } \\
\text { Nutrition }\end{array}$ & $\begin{array}{l}\text { growth and raise } 50 \text { million } \\
\text { people out of poverty by } \\
2022 \text {. G-8 members pledge } \\
\text { to maintain robust } \\
\text { programs to further reduce } \\
\text { child stunting. Commit to } \\
\text { improve tracking and } \\
\text { disbursements for nutrition } \\
\text { across sectors and ensure } \\
\text { coordination of nutrition } \\
\text { activities across sectors. } \\
\text { Eighty private sector } \\
\text { companies have pledged } \\
\text { over } \$ 5 \text { billion in support }\end{array}$ & $\begin{array}{l}\text { implementation } \\
\text { The ONE } \\
\text { Campaign; } \\
\text { InterAction } \\
\text { externally } \\
\text { monitor }\end{array}$ & & $\begin{array}{l}\text { commitments under the New } \\
\text { Alliance, including } \\
\text { commitments made by the } \\
\text { private sector }\end{array}$ \\
\hline $\begin{array}{l}\text { L' Aquila } \\
\text { Food } \\
\text { Security } \\
\text { Initiative } \\
\text { (AFSI) }\end{array}$ & $\begin{array}{l}\text { G-8 and other donors } \\
\text { collectively pledged more } \\
\text { than } \$ 22 \text { billion over } 3 \\
\text { years (2009-2012) to } \\
\text { ensure a comprehensive } \\
\text { strategy focused on } \\
\text { sustainable agriculture } \\
\text { development }\end{array}$ & $\begin{array}{l}\text { AFSI } \\
\text { Working } \\
\text { Groups on } \\
\text { AR4D and } \\
\text { MFDR } \\
\text { The ONE } \\
\text { Campaign }\end{array}$ & $\begin{array}{l}\text { AFSI donors } \\
\text { report on } \\
\text { pledges, } \\
\text { commitmen } \\
\text { ts and } \\
\text { disburseme } \\
\text { nts }\end{array}$ & $\begin{array}{l}\text { Donor reports were made } \\
\text { public towards end of reporting } \\
\text { period }\end{array}$ \\
\hline
\end{tabular}

Following this brief discussion of monitoring efforts regarding major international nutrition commitments made by various governments, international bodies and other agencies, the following section looks at more generic monitoring tools for nutrition outcomes, inputs and outputs that are not specifically linked to pre-defined government commitments.

\subsubsection{Generic nutrition monitoring tools}

Key nutrition outcome indicators such as stunting, wasting and undernourishment are monitored at country level through demographic and health surveys (www.measuredhs.com) and Multiple Indicators Cluster Surveys (MICS), using nationally representative sampling techniques. These survey findings are publicly accessible through the internet. Non-anthropometric indicators on food consumption and food expenditure are collected through household budget and expenditure surveys, however these rarely use methodologies allowing for comparisons across countries and over time. Several indices have also been developed that allow for cross-country comparisons for nutrition outcomes. These tools chiefly support the accountability of governments towards citizens by offering cross-country comparisons. A much wider range of agencies, movements and instruments also provide important information on nutrition inputs and outputs that can support accountability initiatives. Below we set out the main ones, starting with general tools, followed by a discussion of various indices that are of relevance. ${ }^{12}$

\footnotetext{
${ }^{12}$ Currently, the Child Investment Fund Foundation is in the process of commissioning a first Global Nutrition
} Report, for annual publication starting in 2014. 
The WHO Landscape Analysis assesses stakeholders' commitment and capacity to scale up evidenceinformed interventions. It aims to ascertain country readiness to accelerate action on nutrition, in order to guide where to invest and how to best invest in nutrition interventions. The Landscape Analysis contains three components, reflecting diverse aspects of nutrition inputs, outputs and outcomes. A development of country typologies for 'readiness' draws on nutrition input data on policy and governance, and uses health care capacity data as a proxy for nutrition capacity. In depth Country Assessments concern a country's commitment, capacities and resources, and identifies promising actions that could be scaled up to improve nutrition. Its main aims include establishing the current status of nutrition action in a country, thus allowing future progress to be tracked against that baseline. Finally, the Nutrition Landscape Information System (NLiS) is a web based tool that offers users automated country profiles and user-defined downloadable data regarding causes of malnutrition and the status of a country's nutrition, health, and development outcomes (http://www.who.int/nutrition/landscape_analysis/en/). It also reports on a set of capacity related variables.

\section{$\underline{\text { REACH }}$}

The UN inter-agency partnership (FAO, UNICEF, WHO, WFP and IFAD) REACH, (Renewed Efforts against Child Hunger and Undernutrition) operates at country level (in 12 high-burden countries) to build institutional capacity and facilitate a multi-sectoral process to help national governments plan, prioritise and manage more effectively nutrition actions among multiple stakeholders. REACH is placing a strong emphasis on analytics and monitoring \& evaluation as it supports countries in assessing the current nutrition situation and facilitates continuous monitoring of implementation progress.

\section{Scaling Up Nutrition (SUN)}

The initiation of the SUN movement in 2010 brought together fragmented voices amongst development partners and aid recipient countries to closely work towards a unified approach addressing undernutrition. SUN membership now extends to 42 countries. SUN has developed a Results Frameworks that evolve around goals such as universal access to nutritious food, clean water, sanitation, healthcare and social protection; increased adoption of practices that contribute to good nutrition; optimal growth of children, demonstrated as reduced levels of stunting; and improved micronutrient status (SUN 2012). SUN uses a dashboard to show members' progress on key nutrition input, output and outcome indicators. The SUN's tracking system is used to share an appreciation of countries' preparedness for scaling up and accelerate progress. There are three stages identified: taking stock and starting up; ready for scaling up; and scaling up rapidly to deliver results. Results are annually portrayed in the SUN Movement Progress Report which is released in September each year. Country analyses (fiches) are publicly accessible on the SUN website.

While the Results Framework constitutes an important monitoring tool for the donors, the SUN process also constitutes multisectoral and multistakeholder platforms that are designed to enhance constructive dialogue, information sharing and answerability between governments and citizens, private sector and civil society organisations. The SUN movement is guided by a 'multi-stakeholder stewardship' approach. Key bodies involved concern (Mannar 2012: 4-5): 
- Lead Group: Strategic guidance for the Movement is provided by the SUN Lead Group. The Group is charged with providing high-level leadership and strengthening global visibility of nutrition and the SUN Movement. Nominated by the UN Secretary-General, the 27-member Lead Group includes heads of state from developing countries, civil society leaders, donors, business leaders and UN agency directors.

- Country Network: As part of the commitment to scale up nutrition, each country joining the Movement must appoint a national Focal Point, a high-level individual with the ability and access to serve as the point of coordination and mobilise teams across government ministries, external partners and the broader community. The identification of Focal Points addresses a key concern highlighted in the 2008 Lancet Series, namely the lack of a clear point of contact for nutrition.

- Networks: Stakeholders, including all national Focal Points, are organised into five constituent Networks (Civil Society, Business, Donors, UN System) designed to encourage sharing of best practices and facilitate communication regarding country needs. Where there are opportunities or needs to engage support and build capacity in technical expertise, resources or other needs for strategic guidance, the SUN Movement facilitates communication between members of the Country Network and leaders of other Networks that bring together groups in support of SUN countries.

- $\quad$ SUN Secretariat: The Secretariat, headed by Dr. David Nabarro, the UN Secretary General's Special Representative for Food Security and Nutrition, serves as the point of coordination between the Lead Group and the constituent Networks. The Secretariat works to ensure that country needs are being addressed, while also monitoring progress, providing guidance on prioritised actions and creating a shared space for advocates across the global community.

The SUN Movement aims to ensure that all stakeholders that can play a role in advancing nutrition goals are following through on commitments and are accountable to both countries and others in the Movement. An accountability framework (Figure 1) introduced in the SUN Movement Strategy summarises the expectations and the means through which the Movement will track adherence. Stakeholders within and outside SUN countries commit to seven principles which are fundamental to the achievement of these objectives. These include being transparent about impact; being inclusive, through multi-stakeholder partnerships; being rights-based and being mutually accountable such that all stakeholders feel responsible for and are held collectively accountable to the joint commitments (SUN 2012). 
Figure 1: SUN Movement Accountability Framework

SUN Movement Accountability Framework

\begin{tabular}{|c|c|c|c|c|}
\hline & $\begin{array}{l}\text { Participating } \\
\text { countries }\end{array}$ & Support Networks & Secretariat (SMS) & Lead Group \\
\hline 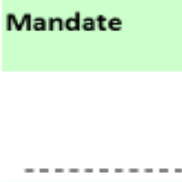 & $\begin{array}{l}\text { - National } \\
\text { Government } \\
\text { (including their } \\
\text { international } \\
\text { obligations }^{1} \text { ) }\end{array}$ & $\begin{array}{l}\text { - Organizational } \\
\text { mandates } \\
\text { - Strategy } 2012\end{array}$ & $\begin{array}{l}\text { - Strategy } 2012 \\
\text { - Road Map } 2010\end{array}$ & $\begin{array}{l}\text { - Strategy } 2012 \\
\text { Lead Group } \\
\text { Statement of } \\
\text { Intent (TBD) }\end{array}$ \\
\hline $\begin{array}{l}\text { Accountable } \\
\text { to... }\end{array}$ & $\begin{array}{l}\text { - Governments and } \\
\text { their citizens } \\
\text { - Parliamentarians } \\
\text { - Investors in } \\
\text { country s.u.n plans }\end{array}$ & $\begin{array}{l}\text { - Individual } \\
\text { Organizations } \\
\text { - Participating } \\
\text { countries } \\
\text { - Lead Group }\end{array}$ & - Lead Group & $\begin{array}{l}\text { Participating } \\
\text { countries } \\
\text { - UN Secretary } \\
\text { General }^{2}\end{array}$ \\
\hline $\begin{array}{l}\text { Results } \\
\text { tracked }\end{array}$ & $\begin{array}{l}\text { - Country Common } \\
\text { Results } \\
\text { - Set own targets } \\
\text { using } \\
\text { recommended } \\
\text { indicators }\end{array}$ & $\begin{array}{l}\text { - } 6 \text { month priorities } \\
\text { and targets } \\
\text { Milestones } 18 \\
\text { month and } 36 \\
\text { month }\end{array}$ & $\begin{array}{l}6 \text { month priorities } \\
\text { and targets } \\
\text { - Milestones } 18 \\
\text { month and } 36 \\
\text { month }\end{array}$ & $\begin{array}{l}\text { Results of the } \\
\text { Lead Group }\end{array}$ \\
\hline $\begin{array}{l}\text { Tracking } \\
\text { mechanism }\end{array}$ & $\begin{array}{l}\text { - Activity Plan } \\
\text { - National platforms } \\
\text { - Self reporting } \\
\text { - SMS tracking } \\
\text { - Annual review of } \\
\text { progress }\end{array}$ & $\begin{array}{l}\text { - Activity Plan } \\
\text { - National platforms } \\
\text { - Network meetings } \\
\text { - SMS tracking } \\
\text { - Annual stock take }\end{array}$ & $\begin{array}{l}\text { - Activity Plan } \\
\text { - Annual appraisal }\end{array}$ & $\begin{array}{l}\text { - Independent } \\
\text { evaluation } \\
\text { - Formal Meetings }\end{array}$ \\
\hline
\end{tabular}

Tracking of progress is undertaken at country level under the responsibility of SUN Government Focal Point(s), responsible for the coordination of internal and external assistance for Scaling Up Nutrition. It is a joint in-country activity that involves representatives from government ministries and departments, as well as from the donor agencies and development banks, the UN system, civil society, business and researchers. They collectively analyse and assess progress in these four processes, identify constraints and work out how best to move forward. Using, and building on, the in-country established monitoring systems, they also track changes and analyse bottlenecks in (a) the intended scale and actual coverage of specific nutrition interventions, (b) the implementation of nutrition-sensitive strategies and (c) commitments (from domestic and external sources) for financial support to Scaling Up Nutrition. The SUN Movement Secretariat works with the Government Focal Points as they track progress and make their information regularly available through country templates. Information from countries will be shared with the SUN global Networks and, if the Government Focal Point agrees, can be made publicly available through the SUN Movement website. The Secretariat analyses data received in the country templates and summarise it -at least annually -in a short document known as the 'Progress Summary Sheet' (SUN 2012).

The SUN constituent Networks are currently establishing goals and clarifying the processes through which they will facilitate support for national efforts. An annual assessment summarising the state of accountability across the Movement is included in the SUN progress report (Mannar 2012). 
MAFSAN

FAO's Mapping Actions for Food Security and Nutrition (MAFSAN) is a web platform to help stakeholders at country, regional and global levels to share information about government investments in food and nutrition security. Although chiefly designed as a repository to collate an overview of policy and financial efforts, its relative ease of access also allows it to perform a basic accountability function.

\section{National Evaluation Platforms}

National Evaluation Platforms offer a systematic approach to collecting nutrition input, output and outcome data, which aims to assess the impact of nutrition interventions. Devised by Johns Hopkins University, this approach has been used in the area of health and efforts are underway to apply the concept to nutrition. Canada is currently supporting the roll-out of national evaluation platforms for maternal, newborn and child health in four countries. The platforms will include the collection of nutrition data. The European Commission is also currently consulting a range of stakeholders on how such Platforms and Nutrition Information Systems could be devised to support its monitoring of commitments made at the Nutrition for Growth Summit.

\section{OECD-DAC Creditor Reporting Mechanisms}

The OECD-DAC Creditor Reporting Mechanism currently is the most comprehensive data source on bilateral donor financing for food security, agriculture and nutrition. It records annual spending by a range of thematic codes. It is however not without fault. The breakdown of total donor aid for nutrition is notoriously difficult to make (Coppard and Zubairi 2011; Di Ciommo 2013; ACF International 2012a). Allocations of funds to thematic codes is not guaranteed to happen in a consistent manner by OECD members. Multilateral aid flows are not captured in a comprehensive manner that allows for making cross-country comparisons. As diverse donors have differential preferences for supporting food security and nutrition through bilateral and multilateral channels, it is currently not possible to compare countries for their total spending patterns without making some grand assumptions.

\section{Food Security Commitment and Capacity Profile}

FAO is currently developing a 'balanced scorecard methodology' to monitor countries' commitment towards food and nutrition security, and their capacity to act on this. The scorecard is currently in the design phase, and will be the main instrument through which FAO seeks to deliver on its medium term strategic objective of enhancing political commitment to food and nutrition security across the globe. The scorecard is envisaged to inform dialogue between national authorities and development partners, and will be in the public domain with easy access to citizens and citizen groups (FAO 2013).

\section{$\underline{\text { Nutrition barometer }}$}

The nutrition barometer (Save the Children/World Vision) offers a scorecard with nutrition input, output and outcome indicators for 36 developing countries, aiming to foster greater accountability for governments. 


\section{Social accountability mechanisms}

Further to the instruments and tools outlined above, internationally a growing range of social accountability tools are being used, at national and subnational government levels, and in some occasions already for enhancing nutrition outcomes. Some include Public Expenditure Tracking; Scorecards, and community audits, etc (Bjorkman and Svensson 2009). These tools are beyond the scope of this review.

\subsubsection{Indices}

The last few years has witnessed a steady proliferation of new metrics regarding hunger and nutrition, many taking the shape of an index. They all perform an accountability function, however their emphasis differs. Some focus on accountability for nutrition outcomes (e.g. Global Hunger Index, Hidden Hunger Index), others on outcomes and inputs (Global Food Security Index), whereas a third focus on accountability for government inputs and outputs (Hunger And Nutrition Commitment Index). While most indices focus on developing countries, some also scrutinise donor countries (HANCI Donor Index) and major global food corporations (ATNI).

\section{Global Hunger Index}

The longest established index of its kind, the Global Hunger Index (GHI) is annually calculated (for 120 countries in 2013), and focuses on hunger outcomes. The GHI combines three equally weighted indicators into one score: the proportion of people who are undernourished, the proportion of children under five who are underweight, and the mortality rate of children younger than age five (IFPRI 2012).

\section{Hidden Hunger Index}

The Hidden Hunger Index assesses chronic deficiency levels regarding essential vitamins and minerals (micronutrients) (Muthayya et al. 2013). This index shows 1) national prevalence data on stunting, anemia due to iron deficiency, and low serum retinol levels among preschool-aged children in 149 countries; and 2) estimates of Disability Adjusted Life Years (DALYs) attributed to micronutrient deficiencies in 136 countries. The tool and maps of global hidden hunger aim to help prioritise program assistance, and to serve as an evidence-based global advocacy tool. Like the GHI, it is outcome focused.

\section{Global Food Security Index}

The ElU's Global Food Security Index compares 107 countries for 27 indicators on food availability, affordability, quality and safety. Several refer to nutrition inputs (e.g. existence of nutritional standards; nutrition plan or strategy) and outputs (e.g. aggregate micronutrient availability in a country) (http://foodsecurityindex.eiu.com/).

\section{Hunger And Nutrition Commitment Index (HANCI): Developing Countries}

Unlike previously listed indices, this Index uses input and output indicators to assess government action on hunger and undernutrition, rather than outcome indicators. $\mathrm{HANCl}$ annually measures political commitment to tackling hunger and undernutrition in 45 developing countries. It is the first global index 
of its kind showing countries' relative levels of political commitment to tackle hunger and undernutrition in terms of appropriate policies, legal frameworks and public spending. The index further provides primary data on commitment levels, drawing on expert perception surveys and community focus groups. It aims to develop a commitment metric, to rank governments; to measure what they achieve and where they fail - providing greater transparency and public accountability; to praise governments where due, and highlight areas for improvement; and to support civil society to reinforce and stimulate additional commitment towards reducing hunger and undernutrition (te Lintelo, Haddad et al. 2013a).

\section{Hunger And Nutrition Commitment Index (HANCl): Donor Countries}

This index annually compares 23 donor countries for their performance on 14 indicators of political commitment to reduce hunger and undernutrition in the developing world. It looks at two areas of donor inputs: Policies and Programmes and Public Expenditures (te Lintelo, Haddad and Lakshman 2013b).

\section{ATNI: Access to Nutrition Index}

The Access to Nutrition Index (ATNI) attempts to inform citizens about policies, practices and performance of major global food and beverage manufacturers regarding obesity and undernutrition. By providing companies with a tool for benchmarking their nutrition practices and serving as an impartial source of information for interested stakeholders, ATNI aims to encourage companies to increase consumer access to nutritious products and responsibly exercise their influence on consumer choice and behaviour (Access to Nutrition Index website).

ATNI seeks to stimulate dialogue about ways in which companies can improve their nutrition practices by serving as:

- A means for companies to benchmark their approach to nutrition against their peers and identify areas for improvement; and

- An independent source of information for stakeholders interested in monitoring and/or engaging with the food and beverage industry on nutrition issues (Source http://www.accesstonutrition.org/about-us).

\section{Healthy Food Environments Policy Index}

This index is currently under development, for publication in 2015/16 by the International Network for Food and Obesity/ NCD Research, Monitoring and Action Support (INFORMAS) (www.informas.org). INFORMAS is a global network of public-interest organisations and researchers that aims to monitor, benchmark and support public and private sector actions to create healthy food environments and reduce obesity, NCDs and their related inequalities. It seeks to develop a benchmarking tool to understand temporal and cross-country progress in government action on obesity, for monitoring and accountability purposes. 


\subsection{How well do nutrition accountability tools work?}

One way of answering this question is by investigating the strengths, constraints and missing aspects of existing accountability tools. Yet, information that can answer these questions is scarcely available in the public domain. A review approach as used in this paper thus provides only a partial perspective, presenting findings for a subset of the accountability mechanisms presented above. Many accountability tools are claimed to actively engage and consult with a variety of stakeholders. In some cases such as SUN, or the Country Assessment Frameworks under EWEC, new institutional arrangements to facilitate this have been set up. This offers potential for filling in the dialogic and explanatory function of accountability, and brings diverse perspectives and the voices of plural stakeholders into decision-making processes regarding appropriate interventions towards undernutrition reduction. The methodology applied for this paper however does not allow for a thorough assessment of the quality and inclusiveness of such deliberative processes. Moreover, it is particularly hard to build up an accurate picture of the implicit or explicit rules that govern stakeholders' delivery of commitments; and the existence (leave be the application) of sanctions/rewards for (non)compliance, and their enforcement mechanisms. A key informant interviewing approach could be suitably employed to address these questions in more detail. However, arguably, where new nutrition commitments are made in future, an explicit and upfront demand for these aspects may help to clarify such rules and enforcement mechanisms, rather than depend on the post-summit working out of these. However, conceivably vagueness serves a political function in that it enables progress through an incremental logic of participation rather than a logic of compliance.

\section{Nutrition 4 Growth}

For a number of initiatives on nutrition it is too early to say how well accountability mechanisms work as they are still being designed. These include the $\mathrm{N}_{4} \mathrm{G}$ and EU commitments made under these. Several preliminary observations can however be made.

The N4G accountability mechanism is being designed in consultation with UK civil society groups; accordingly, the dialogic function of accountability is already being performed.

The N4G commitment monitoring is scheduled to be integrated with Scaling Up Nutrition efforts. As such, SUN business, civil society and other networks are now developing commitment tracking systems, however substantial uncertainty persists in tehse networks on how other networks go about doing so (pers. comm, February 2014, anonymised) suggesting there is a need for a larger degree of coordination. Other people involved in organisations that have made pledges such as the World Bank are lacking clarity on how and by whom N4G pledges will be monitored (pers. Comm. October 2013, anonymised). Without a central authority (for instance a lead group of representatives from parties that have made commitments) that drives forward the monitoring process of commitments, much depends on leadership and buy-in within individual networks and organisations, whose delivery of commitments is then likely to be done at different speeds.

Observers (pers. comm, February 2014, anonymised) have also noted that many 4 G commitments are open to interpretation and are not measurable and time bound. For instance, uncertainty exists on which kinds of donor funds can and cannot be used towards fulfilling commitments, avoiding double 
counting between actors. Moreover, discussions are ongoing if monitoring mechanisms should and could take account not just of inputs, but also of impacts on beneficiaries.

In the absence of greater coordination, several organisations have started to self-report on the commitments they have made at the $\mathrm{N}_{4} \mathrm{G}$ summit. InterAction has developed a model for sharing spending data with the U.S. government and others around the UN General Assembly. It uses a reporting framework similar to the G8's L'Aquila pledge, identifying spending by its members in all the countries they operate in, for the following categories:

- Nutrition.

- Agriculture, forestry, fishing, animal husbandry.

- Food aid/food security assistance.

It uses 2012 data as a baseline (nutrition spending $=\$ 62$ million out of a portfolio of $\$ 452$ million) against which spending over the pledge period of 2013-2015 will be compared. Its first report is due September 2014.

InterAction offers just one example of a broader trend. As private sector and civil society actors are increasingly becoming integral partners to international nutrition commitment initiatives, currently a fair amount of fragmented experimentation is taking place on how these actors are embedded in monitoring mechanisms for these initiatives. Much learning remains to be done on what works and what not. Questions to consider in this respect include what kind of monitoring data can these actors be realistically expected to provide? What resources are needed for them to successfully do so? And what kind of supporting structures can facilitate and streamline their contributions?

\section{Every Woman Every Child (EWEC)}

The EWEC accountability framework is exceptionally well-funded ${ }^{13}$ and has some important institutional features. An independent Expert Review Group (iERG) has been empowered to exercise an accountability function regarding the UN Secretary-General's Global Strategy for Women's and Children's Health (GMMB 2013). iERG members are in a good position to provide independent and critical comment, as they sit outside those institutions and governments that implement the Global Strategy. Furthermore, prior to being nominated, iERG members are subjected to a conflict of interest assessment by WHO.

Furthermore, the work of the iERG is guided by a monitoring framework with 18 indicators, which itself was devised by the Commission on Information and Accountability for Women's and Children's Health, chaired by the Prime Minister of Canada and President of Tanzania. iERG uses a country led approach to monitoring, and uses consultations to assess evidence provided by a range of stakeholders. Finally, in addition to providing updates on progress, the iERG is also empowered to make recommendations that go beyond a strict 'on-track/off-track' report, steering discussions on how to accelerate progress and also adapt to changing circumstances. Whether these recommendations are binding requires further investigation, as are any sticks or carrots that the iERG can use to incentivise greater compliance with commitments made. Its Terms of Reference (iERG, 2012) are not clear about this.

${ }^{13}$ To the cost of $\$ 5.6$ million for $2012-2015$. 
Several civil society organisations that made commitments towards the Global Strategy have now commenced reporting on these for accountability purposes. For instance, World Vision International (WVI) announced its EWEC Commitment of US $\$ 1.5$ billon ( $\$ 500$ million through grants and foundations) in support of women's and children's health on $20^{\text {th }}$ September 2010. In 2012, WVI commissioned a review of progress with regard to its commitment with a focus on: validation of the strategic alignment of programming practice with its EWEC Commitment; and an assessment of actual total expenditures made which may be counted towards its EWEC Commitment (e.g. maternal, newborn and child health programmes). The overall assessment concluded that World Vision is firmly on track to meet its full commitment (Crowe, Clarke and Whitehill 2013).

\section{Scaling Up Nutrition (SUN)}

The SUN Movement has emerged as a potentially powerful platform to bring governments and other entities together to drive action to improve nutrition at the national and global levels. Whereas it has established a unique forum for sharing and learning, the Movement must now use emerging evidence to strengthen the resolve of the broader community and show the impact that this coordinated effort can have (Mannar 2012). SUN has devised a clear accountability framework with targets. Countries working to scale up nutrition are adopting national goals that collectively aim to meet the WHA targets by 2025 . The Movement aims to focus on tailoring an approach to ensure nutritional improvements that align with national needs and opportunities, but is not mandated to apply a uniform approach and lacks a strong 'stick' to enforce commitments of members; it is not clear how this affects its ability to track progress.

Domestically, SUN Civil Society Platforms are designed to play an important role in energising civil society and assist them in holding governments to account. These Civil Society Networks are made up of national and international organisations working in various areas including: farmers, fisherfolk, human rights defenders, women's groups, humanitarian and aid assistance agencies, research entities, consumer groups, trade unions and many others. The primary purpose of the Civil Society Network is to align the strategies, efforts and resources of civil society with country plans for scaling up nutrition within the SUN Framework. Organisations within the Civil Society Network work together to build capacity and maximise resources to ensure the greatest impact on nutrition (http://scalingupnutrition.org/the-sun-network/civil-society-network). Yet, some critics of the SUN Movement assert that it uses a 'top-down' approach privileging leaders and experts, and insufficiently involves local communities. Technical interventions are favoured over social, economic and political actions (Right to Food and Watch 2011).

Whereas SUN publishes a substantial amount of data on its website, some civil society organisations consider that a lack of transparent information on nutrition spending, progress and planning is a key binding constraint for effective engagement and accountability at both the international and national levels. To monitor progress, the SUN Movement must clarify where nutrition funds are coming from. Governments, bi-laterals, foundations and other donors all track nutrition investments different-with direct-nutrition investments easier to trace in comparison with nutrition-sensitive investments, which can be integrated across programs and ministries. The SUN Donor Network has taken on the challenge of 1) improving the tracking of investments (Mannar 2012: p.7); 2) calculating and disclosing their 
contribution to progress against key nutritional outcomes; and 3) developing and publishing their own nutrition strategies (ONE Campaign 2013a).

Another challenge for the Movement is the challenge to monitor mutual accountability. To foster this responsibility, stakeholders must make the Movement their own by being invested in not only the programs and efforts on the ground, but invested also in the success of the full Movement. Thus, Mannar argues that collectively, the SUN Movement should define what it is to be a supporter of the Movement and what is expected from those that endorse this approach. Stakeholders should be held accountable for an organisation-wide commitment to nutrition-working to integrate nutrition internally to mirror the coordination that the Movement seeks to achieve at the country-level (Mannar 2012:8). Essentially, Mannar argues that the rules of engagement and internal norms of performance in the SUN Movement members are to be clarified. This is an important step towards enhancing accountability, however the SUN Movement would also need a clear enforcement mechanisms that rewards members' good performance and deters underperformance.

\section{L'Aquila Food Security Initiative (AFSI)}

The pledges of 22 billion dollar funding made at the 2009 L'Aquila Food Security Initiative was characterised by opaque monitoring mechanisms, and difficulties determining the extent to which new monies were disbursed (ONE 2010). Experiences with the L'Aquila Food Security Initiative (AFSI) demonstrated that common frameworks for setting out and reporting on commitments are critical for achieving greater accountability. Arguably, the basic structures of any such frameworks need to be integral to and publicly presented at the time of announcing commitments.

In the case of AFSI, donors agreed to neither a uniform timeframe for delivering their pledges nor a uniform system for measuring progress. Thus, while most donors agreed to report their financial progress in disbursements, the US, Germany and Japan specified that their pledges would be measured in budgetary appropriations or commitments (ONE Campaign 2013b: 88 and 92). Furthermore, when donors made their pledges, they varied the form of their pledges: Canada, France, Italy and the UK pledged disbursements; while Germany, the EU institutions and Japan pledged in commitments; and the US in appropriations (Congressional budget allocations). They did this to account for variations in political, bureaucratic and budgetary differences; however the differences in pledge forms, periods and reporting made it difficult for the $\mathrm{G} 8$ to be held accountable for their commitments. Future pledges should be made with accountability mechanisms in mind, and include comparable pledging and reporting formats (ONE Campaign 2013b).

\section{New Alliance for Food Security and Nutrition}

The New Alliance initiative was received with scepticism by the NGO community, which had concerns about transparency and accountability measures to ensure companies are prioritising the needs of targeted beneficiaries (e.g. smallholders, non-farm workers), and a lack of input from local civil society leaders (ONE Campaign 2012). Priority outcomes for New Alliance private sector investments are narrowly focused on increasing agricultural crop yields through improved technology; a more sustainable and inclusive agenda would need to prioritise nutrition, gender equity, environmental sustainability, and climate response. Neither increased yields nor increased incomes are sufficient to improve the nutritional status of populations, and the G8 and the New Alliance were called on to 
prioritise improved nutritional outcomes and produce a clear overall target and timelines to achieving them (InterAction 2012).

The role of the private sector in enhancing/weakening nutrition outcomes is important, however current accountability mechanisms for delivering nutritious food products tailored to the needs of vulnerable populations, whether through markets or public regulation, are underdeveloped. As private sector actors are at the heart of the New Alliance for Food Security and Nutrition, civil society groups such as Interaction (2012) have argued that they are expected to be held accountable for performance targets beyond mere production, to include improved capacity of smallholder farmers - especially women - to contribute to food security and nutrition, reduce poverty, and achieve positive environmental goals (Interaction 2012). The opaque nature and limited information on the New Alliance has driven misconceptions about the content of the Letters of Intent provided by the 80 companies pledging investments in African agriculture to the tune of $\$ 5$ billion, and which firms are driving the investment agenda (ONE Campaign 2012). More recently, the New Alliance has been called a Trojan horse, as it has driven revisions in agricultural land ownership laws in several countries that are beneficial for businesses but detrimental to local farming communities (the Guardian, 2014). Civil society groups have proposed several measures to be taken to enhance accountability (InterAction 2012; ONE Campaign 2012):

- $\quad$ Private sector firms need to make public their Letters of Intent.

- Investment figures should be complete and regularly updated.

- Investment projects need a common set of indicators to assess their contribution to the New Alliance goals.

- Create annual progress reports to demonstrate long-term commitment. Progress is to be assessed against the G-8 commitment of lifting 50 million people out of poverty over the next ten years.

- Annual reports that summarise the impact of each company's commitment need to be publically available, for review by participating governments and civil society.

- Civil society must be represented on the New Alliance Leadership Council at the global level and in each consultation group and structure at the country level.

- New Alliance private sector partners, like donors, must be transparent about current and committed levels of funding and be guided by the Rome principles, including support for country-led plans. Currently, New Alliance country frameworks do not impose this requirement on private sector parties, beyond meeting financial commitments.

Responding to these critiques, the September 2013 Leadership Council meeting for the New Alliance for Food Security and Nutrition endorsed a draft Accountability Framework that sets out how New Alliance partners will measure and report results to the African Union, the G8, civil society and other external stakeholders. Recognizing the importance to build on and feed into existing national plans and frameworks such as the CAADP Results Framework and the CAADP review processes and reporting mechanisms, the proposed accountability process for the New Alliance will also be integrated at the country-level and include a single private sector reporting process.

\section{Generic accountability tools}

Finally, for most of the generic nutrition accountability tools, that is, those that are not tied to specific commitments and pledges (e.g. WHO Nutrition Landscape Analysis and including a set of indices), it is 
often not clear whether these provide more than simply another source of information. Thus, while such data is premised to enable greater scrutiny of government inputs, outputs and nutrition outcomes, the extent to which such data is used by stakeholders to hold governments (or private sector companies) to account is not known. Whereas it is reasonable to assume that this data is accessible for policy advocacy, it could be worth assessing the extent, purposes for which it is used, how credible their findings are for policymakers, and their impacts on driving policy change promoting better nutrition. As indices on hunger and nutrition proliferate, there is a greater need for understanding their impact on policy and policy discourse. The Hunger And Nutrition Commitment Index is accordingly now being assessed for its use, and its added value for civil society groups for advocacy purposes and for influencing public policy and key stakeholders.

\subsection{Missing entry points for accountability agents}

This section identifies a number of gaps, which filling would contribute to better performing accountability mechanisms. We identify which are needed to be addressed in the long, medium and short term, and which are critical to be addressed for delivering on international nutrition commitments. We start with recommendations regarding the architecture of accountability for international nutrition commitments, and then discuss specific aspects of nutrition data at national and subnational levels that need improving to become an important evidence base that allows assessment of progress on international nutrition commitments.

\section{The architecture of accountability mechanisms for international nutrition commitments}

- Most accountability mechanisms for international nutrition commitments engage with aspects of evidence, dialogue and (less pronouncedly) monitoring. Harder to establish aspects of accountability, such as rules of engagement and rules of membership, combined with clear enforcement mechanisms that incentivise good and disincentivise bad behaviour appear to be an afterthought. Thus, even the most advanced international initiatives that seek to help deliver nutrition commitments, such as the SUN Movement and EWEC, have as yet only weakly developed (and publicised) enforcement mechanisms. Consequently, the enforceability of international nutrition commitments should not be assumed as a given.

- The review found it particularly hard to build up an accurate picture of the implicit or explicit rules that govern stakeholders' delivery of commitments made in international fora and summits; the existence (leave be the application) of sanctions/rewards for (non)compliance; and the existence and effectiveness of possible mechanisms that enforce these. Where these rules and enforcement mechanisms exist, more transparency about their nature would leverage greater accountability for nutrition commitments. Where they do not exist, accountability mechanisms will remain weak, and the enforceability of commitments subject to substantial uncertainty. Further primary research may be commissioned to explore the political economy factors that make it so hard to develop and agree on rules of engagement and enforcement mechanisms.

- Perhaps one reason why the MDGs were relatively successful in mobilising both international and domestic political support for a diverse group of development standards was that its time 
horizon of 15 years offered a more realistic timeframe within which accountable institutional mechanisms could be developed. In contrast, most nutrition commitments have a much shorter time horizon; typically less than 5 years (e.g. AFSI, N4G, but not the WHA targets), tied to domestic electoral cycles of international political leaders that initiate these commitments. However, short time horizons sit uneasily with the development of accountability systems that depend on incremental approaches and logics of participation rather than logics of compliance.

- The role of the private sector as actors in international nutrition commitment initiatives is important, and so is their role as market actors that could enhance/weaken nutrition outcomes. However current accountability mechanisms for delivering nutritious food products tailored to the needs of vulnerable populations, whether through markets or public regulation, are underdeveloped. It will be important to engage with the private sector and the food industry to assist in developing improved products, market mechanisms, and streamlined delivery channels (Fanzo and Pronyk 2010).

- Whereas substantial yet highly diverse accountability structures have emanated from diverse initiatives (N4G; SUN; EWEC, etc.), for parties that have to hold others to account, it is not always clear what these commitments look like in their entirety due to their fragmentation across initiatives. A central register on nutrition commitments may be established in the short run to provide and maintain an up to date, and complete overview of commitments by different public, private and third sector actors. Such a register would also have to show which commitments are new and additional, and which are not.

- There is a substantial amount of experimentation concerning self-reporting mechanisms for nutrition commitments. Self-reporting mechanisms are an example of the incremental approach and a response to a lack of centralised authority in charge of monitoring and enforcing international nutrition commitments. Whereas self-reporting mechanisms could make a valuable contribution to enhanced accountability, in the absence of strong coordination and common rules on how to report on delivery of commitments, there is a real risk of this leading to a cacophony of approaches that are difficult to compare, assess, and add up.

- Common frameworks for setting out and reporting on financial and other kinds of commitments are critical for achieving greater accountability for nutrition commitments. Existing nutrition commitment initiatives should as a priority develop such frameworks, identify indicators that are SMART and drawing on international best practice and paying sufficient attention to the diverse needs of public, private and third sector actors that sign up to these. Reviews of such best practice may be commissioned to identify a series of principles and approaches that may be applied to nutrition commitments and to make the most of current disjointed learning in this respect by various actors.

- For future international nutrition commitment initiatives, common frameworks for setting out and reporting on commitments need to be integral to and publicly presented at the time of announcing commitments. This will be particularly pertinent for those initiatives that have a relatively short time horizon (less than 5 years). 


\section{Nutrition output and outcome data gaps}

The current key challenges with nutrition data are as follows:

- More than a substantial number of African countries lack nutrition status data, and many more countries lack reliable nutrition output data on the coverage and quality of programs. Where data on status outcomes is produced through nationally representative sample surveys, it is often done so infrequently, less than every three to five years. Where data is produced more frequently through routine monitoring, it is of varying quality and often unstandardised. Recent warnings have been sounded about the validity of data presented by African statistical offices (Jerven 2013). This is especially problematic in settings which are affected by frequent emergencies (UN 2012) and in high risk settings (Fanzo and Pronyk 2010), impeding greater accountability (Nutrition for Growth 2013: 4-5). To address this, FAO with Gallup World Poll is currently developing a new FAO-certified standard for food security monitoring that may be easily adopted by other household surveys (UN 2012). Clearly, basic data on nutrition statuses is critical for informing policy action, and further investments are needed now to ensure that in the medium term affordable and reliable nutrition monitoring instruments can be employed by all countries.

- MDG1 indicators on children under five years of age who are underweight and the proportion of the population who are undernourished are not the best indicators to assess hunger, food security and the health of a population. Countries may benefit from simplifying and streamlining alternative core nutrition measures, such as mid-upper arm circumference (MUAC) for acute malnutrition. Stunting, the height for age of children under five years of age, provides a better indicator to assess the long -term impacts of hunger, poor nutrition and poverty (Fanzo and Pronyk 2010; Haddad and Corbett 2013; Mannar 2012). These, and commitment to hunger and undernutrition reduction should be indicators to be assessed as a potential post-2015 development goal (te Lintelo, Haddad et al. 2013a).

- The potential for expanded support and integration of nutrition into goals across health and development offers an opportunity to address the underlying causes of malnutrition, to position nutrition as necessary and central to the success of broader efforts (Mannar 2012: 6). In the medium term, monitoring the extent to which integration is done, and how to do it, could be of strategic importance, given that currently no such data exists.

- Equity in nutrition: while (horizontal) iniquitous distributional outcomes between social groups (differentiated by gender, ethnicity, race, class, etc) or between geographic areas are common in many countries, data on these are rarely routinely collected and made available, either due to a failure to design for this, or due to data aggregation practices that obscure these.

Consequently, tracking whether nutrition interventions reach the populations most in need; their cost-effectiveness, and the distributional effects of such interventions is severely impeded. In the medium and long term, socially progressive and more accountable policy interventions require better nutrition data, disaggregated for equity.

- Real time nutrition data collection using mobile technology is gaining traction as an idea, as it offers potential for easier and quicker access to data that can demonstrate what works and 
what not at community, district and country levels. However, while work on developing appropriate real time nutrition monitoring methodologies is ongoing, these have not been fully developed as yet, and their practical feasibility remains to be demonstrated (Barnett et al. 2013). Assessments of the cost-effectiveness of real time monitoring instruments for nutrition could be a sensible short run investment strategy.

- The High-Level Panel Report on the Post-2015 Development Agenda also emphasizes the importance of addressing data gaps and enhancing donor accountability for the post-2015 agenda, suggesting initiatives to improve the quality and quantity of public statistics. This indicates an increasing global recognition of the importance of data collection for monitoring results and keeping donors accountable, which could be leveraged to improve global nutrition monitoring tools.

\section{Capacity to deliver nutrition programmes}

- Globally and at national level, data on nutrition delivery capacity (through public, NGO, or private delivery mechanisms; the existence of training facilities at degree and vocational levels; the availability of qualified trained staff etc.) is weak, often outdated and not collected in a systematic manner enabling international comparisons. Whatever capacity data exists is aggregated at national level. At subnational level, administrative capacity to collect and maintain nutrition data systems is often severely constrained, even though subnational units (such as districts, woredas, etc.) are critical loci of policy and programme implementation. Consequently, efforts to enhance delivery capacity in areas that most need it are impeded. Strengthening data generation and maintenance systems on capacity are therefore a matter of urgency (Fanzo and Pronyk 2010). Operationalised at subnational levels, these have real potential to enhance accountability relations between governments to local citizens, especially where this involves greater transparency of and access to disaggregated data. While some efforts are now undertaken to collate country capacity profiles, notably the WHO Nutrition Landscape Information System, these have to resort to crude proxy indicators such as GDP per capita. FAO is currently developing a primary research based assessment of capacity using expert perceptions in its member countries. This has the potential to become an important data source, however, should not detract governments from collecting their own routine data on capacity indicators.

- Nutrition tends to be part of the mandate of health systems, although efforts are spreading to use sector wide approaches for nutrition. Health systems are in need of strengthened information systems enabling better $M \& E_{\text {; }}$ premised on greater capacity to effectively generate, manage, disseminate and utilise health information at all levels of the sector for programme management and development. Such information includes measures with immediate relevance to nutrition, such as effective vital statistics and birth registration systems (http://www.who.int/woman_child_accountability/en/). Integral to developing these information systems will have to be efforts to train nutrition staff to design and effectively use monitoring and information systems (pers. Comm. October 2013 anonymous). Moreover, in the medium run, where nutrition trained staff are increasingly employed in a wider range of sectoral agencies (agriculture, health, social protection, etc.), coterminous development of the receiving agency's capacity of to effectively integrate and use these human resources will be required. 


\section{Financial inputs and donor accountability}

- In the short run, there is a priority need to establish nutrition funding requirements at the national level. To move from the broad cost assessments (Horton, Shekar et al. 2010) to identify country-specific needs, countries need to estimate costs associated with implementation of national nutrition plans, strategies and programming, and to assess funding gaps. SUN Networks are currently undertaking such an effort, in order to facilitate donor alignment of efforts to support full implementation (Mannar 2012).

- Most low income countries still do not have a budget line that calculates nutrition spending (ONE Campaign 2013a). In the short run, establishing nutrition budgets would be a first step towards enhanced capacity to monitor public expenditure data on nutrition, which currently is either not routinely collected in a standardised manner or missing in many developing countries. It would be desirable from an accountability and social contract perspective to know what shares of public expenditures on nutrition in developing countries are funded by domestic sources versus donor sources. International efforts to regular map these spending flows, for instance in a Global Nutrition Report, could incentivise countries to give this greater attention.

- Attributing impacts in terms of improved nutrition outcomes for different types of nutrition investment, whether public or private, constitutes a serious challenge. For example, very little is known about the impact of business investments in nutrition, or of nutrition sensitive investments in agriculture, social protection etc. Financial spending indicators would make more meaningful indicators for accountability once their relation to impact is clearer.

- Multilateral agencies such as WHO (Chopra, Pelletier et al. 2009; Engesveen, Nishida et al. 2009), FAO (pers comm.), UNICEF, the SUN Secretariat (SUN 2010; 2011; ACF 2012; Mannar 2012; SUN 2012b; 2012C) and others (REACH 2012) have commenced monitoring commitments of aid recipient countries to address hunger and undernutrition.

- How can the performance of donor countries towards addressing hunger and undernutrition be made more accountable? Literature on this topic is thin but expanding (ONE 2010; Coppard and Zubairi 2011; ACF International 2012b; 2012a; Di Ciommo 2013; ONE 2013). This critical gaze has however not yet been sufficiently extended to bilateral and multilateral donors and philanthropic foundations (te Lintelo, Haddad et al. 2013b). OECD bilateral aid categorises nutrition spending, but suffers from substantial inaccuracies (Coppard and Zubairi 2011; Di Ciommo 2013). 'The CRS database is problematic to use for detailed tracking of ODA to the nutrition sector due to poor donor reporting practices and limitations with the CRS database itself' (ACF International 2012a, executive summary) and thus do not allow a proper monitoring of spending on food and nutrition' (ACF International 2012b: 41). Greater international collaborative action is needed to devise new methodologies to more accurately map these aid spending flows. This will need to be done simultaneously with improving monitoring mechanisms at national level, to demonstrate that accountability for financial flows is equally the business of aid donor as well as aid recipients. 


\section{Bibliography}

ACF International (2012a) 'Aid for nutrition - Can Investments to Scale Up Nutrition Action be Accurately Tracked?', Action Contre la Faim International 72, London: ACF International.

- (2012b) 'Under the SUN - Tracking Progress of the Scaling Up Nutrition

Movement in Bangladesh and Niger', Action Contre la Faim International 66, Paris: ACF International.

Anon (2013) 'Nutrition for Growth Accountability', First Draft for Consultation, 25/07/2013.

Barnett, I. and Gallegos, J. (2013) 'Using Mobile Phones for Nutrition Surveillance: A Review of Evidence', IDS Evidence Report 1, Brighton: IDS.

Bjorkman, M. and Svensson, J. (2009) 'Power to the People: Evidence from a Randomized Field Experiment on Community-Based Monitoring in Uganda', The Quarterly Journal of Economics 124.2: 735-769.

Brinkerhoff, D.W. (2004) 'Accountability and Health Systems: Towards Conceptual Clarity and Policy Relevance', Health Policy and Planning 19.6: 371-379.

Chopra, M.; Pelletier, D.; Witten, C. and Dieterich, M. (2009) 'Assessing Countries' Readiness: Methodology for In-depth Country Assessment', SCN News 37: 17-22

Coppard, D. and A. Zubairi (2011) Nutrition Advocacy Landscaping in Europe - An Analysis of Donor Commitments, Development Initiatives 96, Bristol.

Crowe Clark Whitehill (2013) An Independent High Level Assessment of World Vision International's Commitments to the UN-Secretary General's Global Strategy for Women's and Children's Health 'Every Woman Every Child', World Vision International, July 2013.

Di Ciommo, M. (2013)The Aid Financing Landscape for Nutrition , Development Initiatives: 159, Bristol.

European Commission (2013) EU Action on Nutrition in Development Cooperation, MEMO/13/517, http://europa.eu/rapid/press-release_MEMO-13-517_en.htm, (accessed 7 June 2013).

Engesveen, K; Nishida, C.; Prudhon, C. and Shrimpton, R.(2009) 'Assessing Countries' Commitment to Accelerate Nutrition Action Demonstrated in PRSPs, UNDAFs and Through Nutrition Governance', SCN News 37: 10-16.

FAO (2013) Acting on Food Insecurity and Malnutrition: The Food Security, Commitment and Capacity Profile, January 2013 Draft (accessed 16 September 2013). 
Fanzo, J. and Pronyk, P. (2010) An Evaluation of Progress Toward the Millennium Development Goal One Hunger Target: A Country-Level Food and Nutrition Security Perspective, Report for the UNDP MDG Task Force for 2010 MDG Summit. Available at: http://www.undg.org/index.cfm?P=327 (accessed on )

Ford, L. (2012) Ban Ki-Moon Launches Zero Hunger Challenge at Rio+20 Summit, The Guardian, 22 June 2012, http://www.theguardian.com/global-development/2012/jun/22/ban-ki-moon-zero-hungerchallenge (accessed 19 September 2013)

GAIN (2013) Access to Nutrition Index, Global Alliance for Improved Nutrition, www.accesstonutrition.org/about-us (accessed October 2013)

Gillespie, S.; Haddad, L.; Mannar, V.; Menon, P.; Nisbett, N.; and Maternal and Child Nutrition Study Group (2013) 'The Politics of Reducing Malnutrition: Building Commitment and Accelerating Progress', The Lancet 382 (9891):552-69, 10 August 2013.

GMMB (2013), pers.comm.

Government of Antigua and Barbuda (2013) Proposed Plan of Action 2013-2014, Zero Hunger Challenge in Antigua and Barbuda, available at:

http://www.zerohungerchallengelac.org/ab/doc/PlanOfActionFinal230113.pdf

Gupta, A. (2012), Red Tape, Bureaucracy, structural violence and poverty in India, Duke University Press.

The Guardian, G8 New Alliance condemned as new wave of colonialism in Africa, 18 February 2014, http://www.theguardian.com/global-development/2014/feb/18/g8-new-alliance-condemned-newcolonialism

Haddad, L. and Corbett, H. (2013) 'Embedding Nutrition in a Post-2015 Development Framework', IDS Policy Briefing 3, Brighton: IDS.

Horton, S.; Shekar, M. et al. (2010) Scaling up Nutrition: What will it Cost? World Bank 100, Washington DC: World Bank.

iERG (2012) Independent Expert Review Group on Information and Accountability for Women's and Children's Health: Terms of Reference, Every woman every child, available at:

http://www.everywomaneverychild.org/images/content/files/accountability_commission/ERG_Ter ms_of_Reference.pdf

IFPRI (2012) Global Hunger Index -The Challenge of Hunger: Ensuring Sustaibable Food Security Under Land, Water and Energy Stresses, International Food Policy Research Institute, http://www.ifpri.org/book-8018/ourwork/researcharea/global-hunger-index (accessed 5 September 2013) 
InterAction (2012a) Delivering on the promise of a 'New Alliance for Food Security and Nutrition, Policy paper, available at:

http://www.interaction.org/sites/default/files/InterAction\%20New\%20Alliance\%202012.pdf

- (2012b) Secretary Clinton Praises $\$ 1$ Billion Hunger Pledge by InterAction members, News Release, 27 September 2012, available at:

http://www.interaction.org/sites/default/files/og.27.2012\%20Member\%2olmpact\%200n\%2oHunge r\%20-\%20Final.docx.pdf (accessed October 2013)

Jerven, M. (2013) Poor numbers, How We Are Misled by African Development Statistics and What to Do about It, Cornell University Press: Cornell Studies in Political Economy.

te Lintelo, D.; Haddad, L.; Lakshman, R.; and Gatellier, K. (2013a) Hunger And Nutrition Commitment Index (HANCl 2012): Measuring the Political Commitment to Reduce Hunger and Undernutrition in Developing Countries, Brighton: IDS, available at:

http://www.ids.ac.uk/files/dmfile/HANCl_2012_reportv2.pdf (accessed 6 September 2013)

te Lintelo, D.; Haddad, L.; Lakshman, R. (2013b) Hunger And Nutrition Commitment Index (HANCl 2012)

'Measuring the Political Commitment to Reduce Hunger and Undernutrition in Donor Countries', http://www.ids.ac.uk/files/dmfile/HANCl_2012_reportv2.pdf (accessed 6 September 2013)

Mannar, V. (2012) Scaling Up Nutrition: Overview of the Movement, report, 21 November 2012.

MeasureDHS, Measure Demographic and Health Surveys, www.measuredhs.com (accessed October 2013)

McLeod, D. (2007) Monitoring MDG 1 Poverty Reduction in Middle Income Countries:

Bulgaria, Moldova, Chile, Costa Rica, El Salvador, Honduras and Mexico, Final report to UNDP-BDP Poverty Group, New York, available at:

http://www.fordham.edu/economics/mcleod/MiddlelncomeMDGıProgress_v3.pdf.

Muthayya, S.; Rah, J.H.; Sugimoto, J.D.; Roos, F.F.; Kraemer, K.; and Black R.E. (2013)'The Global Hidden Hunger Indices and Maps: An Advocacy Tool for Action', PLOS ONE 8.6: e6786o.

Olivier de Sardan, J.P. (2008) Researching the Practical Norms of Real Governance in Africa, Africa Power and Politics Discussion Paper No 5, London: Overseas Development Institute.

ONE Campaign (2013a), The SUN, the Moon and the Stars: A Nutrition Policy Agenda for the next 1,000 Days, ONE Campaign. Available at: http://www.one.org/us/policy/nutrition-for-growth/ (accessed on 12 September 2013).

ONE Campaign (2013b) A Growing Opportunity: Measuring Investments in African Ggriculture, ONE Data report. Available at: http://one-org.s3.amazonaws.com/us/wp-content/uploads/2013/o3/Agfullreport-single-130326-small.pdf. 
- (2012), New Alliance for Food Security and Nutrition: Part 1, ONE Campaign. Available at:

http://www.one.org/us/policy/policy-brief-on-the-new-alliance/ (accessed on 12 September 2013).

- (2010) ONE's Analysis of the G8 Muskoka Statements, One Campaign. Available at:

http://www.one.org/us/policy/ones-analysis-of-the-g8-muskoka-summit-statements/ (accessed on 12 September 2013).

Right to Food and Watch (2011) The Scaling Up Nutrition (SUN) Road Map: A Critique http://www.rtfnwatch.org/fileadmin/media/rtfnwatch.org/ENGLISH/pdf/Watch_2011/Watch_2011_ENG .pdf, p.49-50) (accessed 6 September 2012).

Scaling Up Nutrition (SUN) (2012) Scaling Up Nutrition (SUN) Movement Strategy [2012-2015], ScalingUpNutrition. Available at: http://scalingupnutrition.org/wp-content/uploads/2012/10/SUNMOVEMENT-STRATEGY-ENG.pdf (accessed 5 September 2013).

- (2011) Compendium of Country Fiches, Rome: Scaling Up Nutrition

— (2010) Scaling Up Nutrition Movement Roadmap, New York: Scaling Up Nutrition.

Schedler, A. (1999) 'Conceptualising Accountability', in A. Schedler, L. Diamond, and M.F. Plattner (eds), The Self Restraining State: Power and Accountability in New Democracies, Boulder: Lynne Rienner Publishers.

UK Government (2013) 'World Leaders Sign Global Agreement to Help Beat Hunger, UK Gov News story. Available at: https://www.gov.uk/government/news/world-leaders-sign-global-agreement-tohelp-beat-hunger-and-malnutrition. (accessed October 2013)

UN (2012) UN Secretary-General's Food Security Task Force Commits to Actions to Achieve Zero Hunger Challenge, blog, http://www.un.org/en/zerohunger/newmetric.shtml (accessed 19 September 2013)

- (2012) Millennium Development Goals and Beyond 2015, United Nations Foundation, www.everywomaneverychild.org/commitments (accessed October 2013)

US Government (2012a) L'Aquila Food Security Initiative, 2012 US Government Report. Available at: http://www.state.gov/documents/organization/202922.pdf. (accessed on 15 September 2013)

- (2012b) Fact sheet: G-8 Action on Food Security and Nutrition, The Whitehouse Office of the Press Secretary, 18 May 2012. Available at:

http://www.whitehouse.gov/the-press-office/2012/05/18/fact-sheet-g-8-action-food-security-andnutrition (accessed on 15 September 2013)

Villar, E. and Dodd, R. (2005) Squaring the Accountability Triangle, D+C, Magazine for Development Cooperation 8/9. 


\section{CHILDREN'S \\ INVESTMENT FUND FOUNDATION}

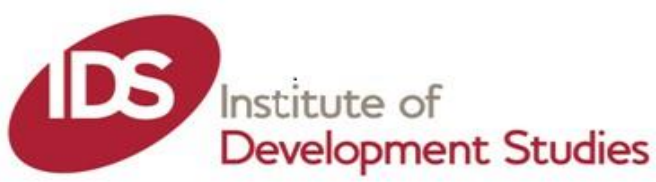

WHO (2013) Essential Nutrition Actions: Improving Maternal, Newborn, Infant and Young Child Health and Nutrition, Geneva: World Health Organisation. Available at: hhttp://apps.who.int/iris/bitstream/10665/84409/1/9789241505550_eng.pdf (accessed 5 September 2013)

(2013) Accountability for Women's and Children's Health, World Health Organisation, www.who.int/woman_child_accountability/ierg/en/ (accessed October 2013)

- (2012a) Sixty Fifth World Health Assembly, WHA65/2012/REC/1, Geneva, 21-26 May 2012. Available at: http://www.who.int/nutrition/topics/WHA65.6 resolution_en.pdf.

- (2012b) Every Woman, Every Child: From Commitments to Action: The First Report of the Independent Expert Review Group (iERG) on Information and Accountability for Women's and Children's

Health, Geneva: World health Organisation. Available at: http://www.who.int/woman_child_accountability/ierg/reports/2012/en/ (accessed 14 September 2013)

WHO and UNICEF (2013) Accountability for Maternal, Newborn \& Child Survival: The 2013 Update, Countdown to 2015 Maternal, Newborn and Child Survival, Geneva: World Health Organisation. Available at: http://www.countdown2015mnch.org/documents/2013Report/Countdown_2013Update withprofiles.pdf (accessed 15 September 2013)

(2012) Building a Future for Women and Children: The 2012 Report, Countdown to 2015 Maternal, Newborn and Child Survival, Geneva: World Health Organisation. Available at: http://www.countdown2015mnch.org/documents/2012Report/2012-complete-no-profiles.pdf (accessed 15 September 2013)

World Bank (2003) World Development Report 2004, World Bank, USA: Oxford University Press. 